University of Louisville

ThinkIR: The University of Louisville's Institutional Repository

Electronic Theses and Dissertations

6-1948

\title{
The history of the government of the city of Louisville.
}

Attia Martha Bowmer

University of Louisville

Follow this and additional works at: https://ir.library.louisville.edu/etd

Part of the History Commons

\section{Recommended Citation}

Bowmer, Attia Martha, "The history of the government of the city of Louisville." (1948). Electronic Theses and Dissertations. Paper 1869.

https://doi.org/10.18297/etd/1869

This Master's Thesis is brought to you for free and open access by ThinkIR: The University of Louisville's Institutional Repository. It has been accepted for inclusion in Electronic Theses and Dissertations by an authorized administrator of ThinkIR: The University of Louisville's Institutional Repository. This title appears here courtesy of the author, who has retained all other copyrights. For more information, please contact thinkir@louisville.edu. 
THE HISTORY OF THE GOVERNMEINT

OF" THE CITY OF IOUISVILLE

\section{A Dissertation}

Sabmitted to the Faculty

Of the Graduate School of the University of Louisville

In partial fulfillment of the Requirements

For the degree

of Master of Arts

Department of History and Political Science

By

Attia Martha Bowmer

Year

1948 
Name of Student:

ATIIA M. BOWMER

Title of Thesis: THE HISTORY OF THE GOTARNMENT OF THE CITY OF IOUISVIILE $1780-1870$

APPROVED BY READING COMMITTIE

COMPOSED OT THE FOLLOWING

MEMBERS:

NAME OF DIRECTOR:

DATE: JUNE 1,1948 


\section{TABLE OF CONTENTS}

CHAPTER

PAGE

I. IOUISVILIE UNDER THE TRUSTHES 1780-1827

A. Background of Municipal Development

in the United States............ : 1

B. Farly Political Development of Louisville . . . II

II. LOUISTIIIE UNDIFR THE FIRST CHARTHR 1828-1850

A. Introduction .............. 29

B. Hlections and Voting . . . . . . . . 32

c. Mayor and Council ............. 43

D. Council and Legislature . . . . . . . 56

III. IOUI SVIILE UNDER THE SECOND CHARTER 1851-1870

A. Introduction ............. 62

B. Elections and Voting.......... 64

c. Meyor and Council ........... 76

D. Council and Iegislature . . . . . . . 94

IV. SUMMARY . . . . . . . . . . . . . . 106

BIBLIOGRAPHY . . . . . . . . . . . . . . . 113

CHARTS AND GRAPHS

1. Structure of Government - Charter of 1828 . . 31

2. Structure of Gorernment - Charter of 1851 . . 65

3. Structure of Government - Charter of 1870 . : 102

4. Graph Votes Cast in Municipal Ilections 1851-1870.............. 72 


\section{PRWFACD}

Most historical writings on the subject of Louisville have treated its social, political, and economic derelopment, but few have even touched on its municipal gorernment. The purpose of this study is to record the history of the governmentel structure of the city of Louisfille from 1780 until 1870 . It is concerned primarily with the type of government, the sources and extent of its power, and its legislative history. The detalls of municipal functions and administration are outside the scope of this witing except as they relate, generally or specifically, to the development of the general framework of the city gorernment.

For the sake of conrenience, this history has been dirided into periods according to the type of government and charter in operation. In each period emphasis is placed upon the relationships existing between the roters and the city council, between the city council and the mayor, and between the state legislature and the council.

Most of the history has been witten from manuscript records, statutes, and other documents. As far as avallable, newspapers of each perlod have also been consulted. 
Background of Municipal Development

At the time of the establishment of Louisville as a torm in 1780, the United States was predominantly an agricultural country, little concerned with problems of urban development. Toms were small and their government still clo eely resembled Inglish borough government which had been transplanted, along with other Inglish traditions, to the American colontes during the serenteenth and eighteenth centuries.

Toward the close of the serenteenth century there were in England some two hundred boroughs with charters from the Crown, enjoging the privileges of corporation, namely: to sue and be sued, to own and administer property and to possess a common seal. ${ }^{1}$ Typically the maniclpality was a closed corporation or an oligarchy with corporate privileges vested in a small number of freemen.

Wile in most Inglish boroughs freemen had the right to vote, the conception of freeman had changed between the thirteenth and seventeenth centuries. The body of freemen, once including all men not bound to the soil, had now become a small group with rery special privileges based on birth, marriage, the ormership of certain lands,

IT. H. Reed. Municipel Government in the United States, p. 59. 
or rank conferred by the borough corporation. To be a freeman did not require residence as a qualification and many of the freemen of a borongh were non-residents. Freemen only voted for members of Parliament, and in addition they were accorded certaln trading pririleges and exemptions from tolls and marked dues, privileges of such pecuniary importance as to enable the king to control Parliament through the threat of withholding them. 2

Although each municipality received its individual charter from the King and the details of organization and titles varied, the governments of boroughs had much in common. The governing body generally was the councll consisting of the aldermen, common councilment, and the mayor, who acted as president. The council sat as one body, and such executire functions as were permitted by their charters were carried out by committees of that group. In most cases, members of the council beld office for $11 f e$ and racancies were filled by rote of the council. In a few of the more populous boroughs, members vere elected vira voce by a fairly large group of freemen. 3

Aside from police and judicial powers, belonging mainly to the mayor, recorder, and certain other chief officers of the commonalty, the main functions of the borough government were the management of corporate property, the direction of the markets, and the election of

2Wm. B. Munro, Municipal Government and Administration, Vol. 1, pp. 49 and 71 ff.

3. H. Reed, Op. Cit., pp. 59-60. 
borough representatives to Parliament. 4 Certain of its officers were. further entrusted by the Crown with the important duties of administering civil and criminal justice. 5

In the American colonies of England charters were granted by the governor, who was the local representative of the Crown. 6 Borough charters were not forced upon the colonial towns but were granted only on petition of a group of towsmen. New England towns never received charters, but were by legislative act permitted to function as local governments within limits.?

The first active colonial borough was established in New York in 1686. Within a short period of time some twenty boroughs were established mostly within a small section covering parts of the present states of New York, New Jersey, and Pennsylvania; to the south were the Virginia boroughs of Williamsburg, Richmond, and Norfolk, and the Maryland town of Annapolis. After 1746 and until the close of the Revolutionary War, with one or two exceptions, no new charters were granted. 8

The structure and functions of colonial boroughs closely

47. I. Goodnow, City Government in the United States, pp. $43 \mathrm{ff}$.

5Ibid.; also, F. A. Pairlie, Essays in Municipal Administration, pp. 49-50.

${ }^{6}$ Munro, Government of American Cities, p. 3; Reed, op. cit, p. 61 .

7 Munro, op. c1t., p. 85.

8vanro, op. cit., pp. 85-86; Fairlee, op. cit., pp. 58-60; Reed, op. cit., p. 61; cf. Fatrile, Fssays in Municipal Government, p. 50 . 
paralleled the contemporary Inglish municipal organization. While detalls of government varied with the indiridual borough, or city, the same general pattern was folloved. These charters usually intrusted governmental authority to the mayor, recorder, a small number of aldermen, and an equal or greater number of assistant aldermen, or common councilmen as they were sometimes called. These men comprised the council and sat together as one body. 9 Following the English pattern, the council performed both executive or legislative functions. Judicial functions were generally discharged by the mayor, recorder, and aldermen, who served as justices of the peace and jointly held courts of civil and criminal jurisdiction. The American borough, like the Ingl1sh, was more concerned with judicial than with admintstrative functions. 10

The relation of the people to the borough government in the colonies differed somewhat from that in Fingland. While in Ingland the closed corporation was the rule, in America it was the exception. Only Philadelphia, Annapolis, and Norfolk were closed corporations. Council members, except in these three town, were generally elected by a fairly sizeable electorate compriaing all freemen and freeholders. In a few boroughs the franchise belonged

\footnotetext{
9. A. Fairlie. Municipal Administration. p. 73.

10 Reed, op. cit.. pp. 61-62; Goodnow, op. cit., p. 52.
} 
also to householders 11

The status of freeman was bestowed by the borough corporation, usually according to charter provisions, and was nowhere subject to the restrictions and abuses prevalent in Fngland. In New York, the mayor, recorder, and aldermen had the power to confer free citizenship on natural-born or naturalized British subjects. Other charters had similar provisions. In most cases the fee charged for admission to free citizenship was limited by charter.

As in Ingland, certain trade privileges, more important in the earlier days than toward the close of the colonial perlod, were accorded freemen; e.g., only the freemen of a borough "could practice any art, trade, mstery, or occupation within the borough, except during the great fairs." 12

The mayor was, in most places, eppointed by the governor. In Elizabeth, howerer, he was elected by the council, and in some of the small boroughs he was elected by a restricted popular vote. The usual term of office was one jear, but in those towns where the mayor was appointed, reappointment was common. ${ }^{13}$ The major had no real executive power. His duty was primarily to preside orer the council.

11 Tairlie, Bssays in Manicipal Admini stration, p. 62 . 12 Ibid., pp. 61-63.

13Ib1d., p. 67; Reed, op. cit.. p. 63. 
In Philadelphia he was not permitted a rote in the council, and in New York he roted only in case of a tie. In no instance had he the power of veto. Unlike the mayor of the English borough, who appointed most of the borough officials, 14 the mayor of the Americen borough generally made no appointments. His importance emanated from his judicial functions and his influence was enhanced by the fact that he had usually gerved as alderman and had had long experience in muntcipal government. Sometimes, too, he held minor offices in the borough, as the Mayor of New York, who served as clerk of the market. The recorder was chosen in the same manner as the mayor. His function seems to hare consisted chiefly of drafting documents and of adrising the council on legal matters. 15 The council, as has already been said, was usually elected by restricted suffrage. The number of members comprising the council varied from borough to borough. Seren aldermen and seren assistant aldermen were elected annually by wards in New York. In Philadelphia the number of aldermen and councilmen was changed from time to time. 16

The council's main function "apart from holding local court and making the bylaws was that of regulating trade and supervising

14 Fairlie, Municipel Administration, p. 73; Munro, Municipal Gorernment, Vol. I, p. 90 .

15 Pairlie, Essays in Municipal Administration, pp. 69-70, 76. 16 Reed, op. cit., pp. 62 and 64. 
the markets. 17 Unt1l about 1750 the borough council had 1ittlo to do, but with the growth of population after 1750, the neods of the poople increased. Since the Council had very limited authority, in most cases having no power of general taxation, they made constant demands on the colonial assembly. This, in turn, gave the assembly inoreased control orer municipal affairs and laid the basis for the state control of cities characteristic of later municipal devel opment. 18

During and after the Rerolution few changes in organization and functions wore ovident. The period from 1776 to 1790 witnessed the ascendency of state control over municipalities.19 The new charters wero granted by the logislature rather than by the governor. The city charter had become a statute, subject to amendment or repeal like any other statute, and the city became subject to legislative interference.

The new state constitution also led to changes in the manner of choosing mayors. In New York the power of appointing the mayor was transforred from the governor to a state executive council. The Philadelphin charter of 1789 provided that the mayor be elected p. $90 .{ }^{17}$ Munro, Municipal Government and Adninistration, Vol. 1, ${ }^{18}$ Reed, op. e1t., p. 63; Munro, op. eit., pp. 89-90.

19 Fairlio, Munioipal Administration, pp. 77-78; Munro, Government of American Cities, p. 5 
by the aldermen from among their number. The principle of federal analogy reared its head in the Baltimore Charter (1797) wich provided that the mayor be chosen by an electoral college; 20 howerer, this was an exception. In general the choice of mayor became the prerogative or the city council or remained the privilege of the governor, but in any case, there was no attempt to transfer trie selection to the people until after 1820 .

Also charactoristic of the early years of the now republic were the disappearance or the close corporation and the establishment of locally elected councils. In 1787 the Virginia legislature provided for the election of the council by freeholders and inhabitants of the borough. The Philadelphia oharter of 1789 provided for a councll composed of rifteen aldormen and thirty common councilmen, the aldermen to be elected by the owners of frsehold property and the common councilmen to be chosen by the "freemen." Administrative officials such as assessors, tax collectors, constables, and others, however, continued to bo appointed throughout the first two decades of the nineteenth oentury. 21

Between the close of the Revolutionary War and 1825 some

20 Munro, Municipal Govornment and Administration, Vol. 1, p. 92; Munro, Government of Amorican Cities, p. 7 .

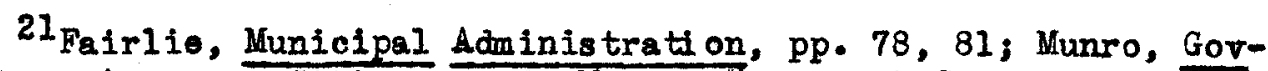
ernment of American Cities. p. 6; Munro, Iunicipal Government and Administration, Vol. I, p. 95 . 
purely American features crept into the system of Municipal government. "The principle of aministrative and legislative autonomy became fetich. . The autonomous mayoralty, the executive sto, and the practice of aldermanic confirmation -- all of them native institutions, and all attributable to the influence of national theories upon local government -- made the ir appearance... "The cherter of the city of Boston (1796) was the first to establish the two-chambered city council. One chamber was composed of two representatives from each of elght wards and the other, of representatires of the city at large.22 Both the first Detroit charter (1806) and the Pittsburg charter of 1816 followed suit in establishing the bi-cameral council.23 This trend of organizing municipalities along the lines of federal government persisted throughout the nineteenth contury.

By 1820 the urban population represented a little less than five per cent of the total population of the United States and only thirteen towns could boast of more than 8,000 inhabitants. The rate of increase in urban population expanding after the Revolutionary War slowed down considerably between 1810 and 1820 before it gained momentum in the following three decades.24 Although the functions

${ }^{22}$ Munro, Gotornment of American Cities, pp. 7-9.

23Fairlie, Munioipal Adminis tration, pp. 79-80. Detroit's charter lasted only until 1809 . pp. 22-24.

24. F. Weber. Growth of Cities in the Nineteenth Century, 
of the municipalities were still relatively unimportant, some public services had been initiated. New York had the beginnings of an organized police system. Most of the larger towns had built some type of public sewer and had made provision for street cleaning. In more populous towns there were sidewalks and oll lamps along the main thoroughfares. Fire protection was in the hands of volunteer companies. Poor relief received some attention and public education was in an incipient stage of development. 25

In summary it may be said that during the poriod following the close of the war there began to evolve out of the colonial borough a distinctive American municipal system. The general organization and functions of the colonial corporation remained almost intact but certain changes, espocially in the relationship of the people to the town government and the tow to the State, were evident. The close corporation wros replaced by locally elected councils, and the mayor was less often appointed. Suffrage, however, was still restricted to the well-to-do classes. The council, more powerful than the mayor, appointed officials and carried on the administrative functions of the government eithor as a body or through council committees. Municipal services were fow and administration, comparatively simple. Louisville's early history coincided with the developments of this post-war period. The first exploring party reached the falls of the Ohio in 1773 and only a few years intervenod before the

25 Munro, Government of American Cities, pp. 8-9. 
settlement on Corn Island in 1778.26 During the fall of the same year the settlers removed to the minland and two years later the Virginia legislature, upon potition of the inhabitants, 27 passed an act ostablishing the tom of Louisville.

\section{Early Political Development of Louis ville}

Louis ville's beginnings were anything but auspicious. The land set aside for the establishment of the town was "2000 acres on the Ohio opposite to the Falls" which had been confiscated on July 1 , 1780, from John Connolly recently convicted of being a British Agent. 28 Connolly, after his trial, had left to join the British, but John Campbel 1, who owned two thousand acres adjacent to Connolly's land and who, at the time of the establishment of Louisville, had boen a British prisoner in Canada, retarned three years later to claim, not only his own land, but a mortgage against the land formerly in Connolly's possession. For the next eight years ho maneuvered in the Virginia logislature to collect that olaim. Whether or not Campbell's clain was legitimate is not known but cortainly the tom of Louisvillo stood to lose wi the every success he won. Campbell and the Virginia

26Iowis Collins. History of Kentucky, Vol. 2, p. 358 .

27 James R. Robertson. Petitions of the Early Inhabitants of Kontucky to the General Assembly of Virginia, 1769-1792. Louisville, 1914 (Filson Club Publication No. 27), pp. 53-55.

${ }^{28}$ Collins, op. cit., Vol. 2, p. 183 . 
legislature were not, however, the only obstacles confronting the trustees. Indian troubles, which made it impossible to hold the scheduled public auction of town lots in April, 1781, 29 11kewise compelled the Virginia legislature to extend three times 30 the period for building on the lots in Louis ville. To establish gorernment when settlement itself s hazardow was no mean feat.

The tow was little more than a frontier settlement in 1780. The exact number of inhabitants is not known, although three hundred families are reported to have settled in Louisville by that date. Kentucky County had just recontly boon carved out of Fincastlo County and four months after Louisville had been named a town, Kentucky County was divided into three counties, Louis ville being designated as the county seat of Jefferson. 31

The act of the Virginia legislature of 1780 named nine trustees for the town of Louisville and vested in them the authority to lay off a thousand acres of land into half-acre lots with convenient streets and public grounds. By tho samo act, they were empowered to sell the lots, to settle boundary disputes, to resell lots if the owners failed to build and to apply such monoy to "ropairs or better-

${ }^{29}$ Record of Town of Louisville 1781-1793.

${ }^{30}{ }_{1786 ;}$; $789 ; 1793$ Acts of the Virginia Logislature relating to Louisvilie, pessin.

${ }^{31}$ Collins, op. elt., Vol. 1, p. 20. 
ment of the city."132 Although no mention is made in the Act of 1780 , the trustees probably possessed the judicial powers customarily bestowed on municipal of ficers of the time. 33

Of the nine original trustees, only one resided in Jefferson County and three others are known to have been inhabitants of Lincoln or Fayette Counties.34 Colonel Durrett remarks that the trustees were appointed by the Virginia legislature "for one reason or another, but seldom if ever, because they were suited by residence or qualification for the office they were to fill." 35

The original trustees, Iike the councils of the close corporations, had the power to fll 11 racancies of the board. Tho legislature passed another act in 1786 granting the same powers to seven commissioners, named in the act; again in 1789 twelve trustees were appointed and in 1790, five commissioners. 36 (There was virtually no difference

32 An Act for establishing the town of Louisville at the Falls of the Ohio, passed by Virginia Legislature, May 1780, loc. cit.

${ }^{33}$ See R. T. Durrett, "Louis ville Under the Virginia Trustees" J. G. Johnston, Memorial History of Louis ville, 1896, p. 47.

${ }^{34}$ Collins, op. cit., Vol, 1, pp. 20 and 366 ; according to Col. Durrett, eight of the nine trustees resided outside Louisvilie. That the trustees were not residents is further brought out in resolution passed by the board at a meoting of the trustees April 22, 1783, which provided that one Mark Thomas "bo paid 24 for boarding the Trustees and their attendants and that the Bursar pay him out of the Sale Lots."

${ }^{35}$ Durrett, op. ait., p. 62 .

${ }^{36}$ Virginia Statutes, 1786 , Ch. 102; 1789, Ch. 66; 1790, Ch. 29, loc. cit., pp. 19, 29,35, 51 . 
in the powers bestowed on trustees and those granted commis stoners. In fact, in the journal of the trustees, the comissioners appointed in 1786 wore designated as "Commissioners and Trustees." $)^{37}$ The selectlon of trusteos, thus, was a privilege belonging primarily to the legislature, secondarily to the trustees themselves, but in no case to the citizens of the town.

The on striking feature of the government of Louisville at this time, Iike that of other towns of the United States, was its complete subordination to legislative control. The trustees were accorded very little discretion by the Virginia legislature and later, when the town had passed from Virginia's jurisdiction to that of Kentucky, their powers were extend ed only slightly.

The first meeting of the trustees recorded was on February 7 , 1781. At that meeting provisions were made for a survey of the town lands, for the widening of Main Street, and for an auction of lots. It wa likewise decidod to petition the General Assembly with regard to the opening of a canal. 38 None of these plans was carried out for many a year. The settlement of the town progressed slowly and there is no record of a socond meeting until June 4, 1783, at which the only business transacted s the appointinent of four trustees. 39 From this

${ }^{37}$ Record of Town of Louis ville, Feb. 14, 1787.

${ }^{38}$ Ib1d., Fob. 7, 1781 .

${ }^{39}$ Ibid., June 4, 1783. 
time on until 1786 moetings were hold infrequently, the trustees concerning themselves primarily with the sale of lots and Campbell's claims.

In May, 1783, further proceedings respecting the salo of lots were sus pended 40 and in October of the same year the Virginia legislature repealed all sections of the act of 1780 which might "prejudice the title of the said John Campbell and Joseph Simon" and prescribed that the lands be divided according to the deed of partition drawn by Campbell and connolly.41 The next year the logislature further decreed that the forme $\mathbf{r}$ Connolly lands should be divided into lots, sold by the trustees, and the money applied to redeeming the mortgage. 42 Apparently, the trustees would not or could not carry out the duties imposed by the legislature, for the following year, 1786, they were compelled to abrogate their powers in favor of a new board of "commissioners."

The difficulties in government increased with the succeeding years. In 1789 trustees were again appointed and their number increased to twelre. 43 Frequent mention of resignations and refusals

40Virginia Statutos, May 1783, Ch. 31, in Colb etion of Acts, 1839, pp. 4-5.

4lvirginia Statutos, Oct, 1783, Ch. XV, ibid., p. 11.

42Virginia Statutes, Oct. 1784, Ch. LXV, ibid., p. 15.

${ }^{43}$ Virginia Statutes, 0ct. $1789, \mathrm{Ch} .71$, 1bid., p. 37. 
to serve by members may be found in the reoords of the board. 44 Due to the fact that "inconveniences [had] arisen on account of the powers given the trustees and commissioners of the town of Louisville ... . not being sufficiently defined" an act os sed in December 1790 providing that the powers of trustees thereafter be rested in fire commissioners whom the act nad. The board of trustees met on the first of the March following but "considering that they cannot proceed until they are possessed of the different acts of assembiy and with the recad of the former trustees aud commissioners respecting the aforesaid Town" adjourned without transacting any business. 45

In 1791, as its last act affecting Louisville, the board returned the title of one thousand acres (the lower thousand acres of the Connolly tract) to John Campbell. 46 The action or the trustees on this matter was perfunctory and indicative of their lack of authority. On June 25, 1793, at the first moting in more tnan two years, John Campbell was ordered to produce to the boerd at the next meeting his accounts of receipts and expenditures. It was also noted that "the above meting was held in pursuance of a law passed by the Legislature oI Virginia" (in 1791).47 At the following meoting in August, Mr. Campbell's

44record of Town 오 Louisville, passim.

${ }^{45}$ Record of Town of Louis v1 11e, March 1, 1790.

${ }^{46}$ Virginia Statutes, 1791, Ch. LXVI, 10c. cit., p. 30.

$47_{\text {Record }}$ of Town 오 Louisville, 1781-1825, p. 36 . 
report is not recorded; there is simply the statement without comment that "John Campbell agreeable to order produced an acoount of his receipts and expenditures and flled among the other papers receired from the former Trustees and Commissioners."

Meanwhile, although Kentucky had been admitted as a state in 1792, three of the trustees appointed by the Virginia legislature nominally continued in office for the intervening years. As Colonel Durrett states, after "Campbell had compelled the trusteos to sell 211 the land given for a town. - there was but little to ongage the attenti on of even so small a number as three." 148

In 1795 the first Kentucky logislation for Louisville was enacted, and several important changes were instituted. This act provided that the trusteos be elected rather then appointed and prescribed that they be "residents and freeholders... and of good reputation." The vote was extended to residents who were "qualified electors who had a right of suffrage for members of the General Assembly," 49 a priviloge wioh the constitution accorded ". . . to all free male oitizens of the age of twenty-one years, having resided in the state two years, or the county in which they expect to rote one year next before the al ection.." 50 In other towns of the

$$
{ }^{48} \text { Durrett, op. oit. , p. } 61 \text {. }
$$

49.An Act concerning Louisville," Dec. 19, 1795, Sec. 1, in Colloction of Acts, $1839, \mathrm{p} .11$.

${ }^{50}$ Kentuaky Constitution, 1792, Art. III, Sec. 2. 
State the right to rote was granted to "erery free malo of the age of eighteen residing in the town or holding a titlo to real ostate therein." 51

The authority of the trustees was extended to include tho power to appoint a clork, to ostablish a market house, to repair streots, to remove nuisanoes and obstructions, to pass ordinanoes and regulations respecting boundaries, to levy and collect taxes not exceoding thirty-five pounds a year. 52 This last was especially important, sino previously maniclpal revenue had depended solely upon the sale of lots.

The same act provided that inspection of tobacco at Campbell's warehouse be suppressed and one establishod in Louisville.53

The following year the legislature fur ther declared that "the forfeitare of no lots shall accrue for want of erecting the necessary buildings thereon within the next five years . . nor at any time thereafter." 54 Thus, by the time the newly olected trustees took office, some of the obstacles to municipal government had been removed.

The yoars between 1795 and 1828 are characterized by a very

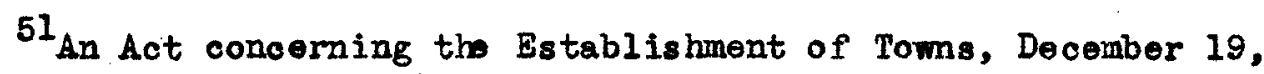
1796, Sec. 3, in Kontucky Laws, 1797.

$$
\begin{aligned}
& 52_{\text {Ibid.., Sec. } 3 .} \\
& 53 \text { Ibid., Sec. } 7 .
\end{aligned}
$$

${ }^{54}$ Kontucky Laws, 1797, "An Act concerning Louisville, passed December 19, 1795, Seo. 1, in Collection of Acts, 1839. 
slight extension of municipel functions attended by frequent grants of power from the logis lature. Although the 1795 Act might appear elastic enough to corer my of the trusteos' actions, the board, nevertheless, sought, 55 and obtaind legislative authorization frequently. As a result, some thirty-one laws concorning Louisville were enacted in this period, 56 extending the a uthority of the trustees to include such powers ass the right to impose penslties for racing and shooting, the power to regulate public springs, to make and record deods of conveyance, to appoint a survoyor of streots, to keep the harbor in good order, to survey the town, to hare polluted ponds cleand and nuisances removed, to make deods, to appoint a commissioner, to procure lists of taxable property, to build a market house, to fill or drain ponds, to pass by-laws relative to the prevention of firo and the collection and appropriation of authorized taxes; to pas by-laws to suppress unlicensed tippling houses; to have streets pared; to assess owners of property for paring; to level and graduate streets; to dig wells; to obtain judgment against colloctors who fail to collect taxes; to purchase and hold real estate for erecting market houses, wharves, etc.;

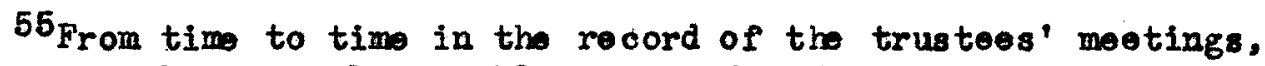
petitions to the general assembly requesting further powers are reported. See, $\bullet . \mathrm{g} \bullet$, Record of Town of Louis ville, 1781-1825, pp. 42, 49,70 , et passim.

${ }^{56}$ Collection of Acts of Virginia and Kontucky relative to Louisvil10, passim. 
to appoint harbor masters; to appoint inspectors of flour; and to require inhabitants to work on roads within the town. 57

A typical examplo of this specific and detailed legislation may be found in the "Act to authorize the Trusteos of Louisville to pave the Streots of said town," approved January 8, 1813. This act gave the trustees the power

to compeli the owers of 1 ots and parts of lots on Main Street... between cross street number three, and cross street number six, to peve in front of their respective lots - . as far as tho middlo of sajd street...

The Act of 1795 stipulated that the re should be soren trustees and that they were to be elected annually. 58 This was changed in 1801 by an act providing for bi-annual elections.59 The eleotion was conducted by the sheriff and held at the courthouse. Vacancies caused by death or resignetion were to be filled by election under the Act of 1795,60 but this must have proved impractical for in 1801 the logislature provided that thereafter racancies should be filled by vote of the remaining trustees until the next general el oction. 61

\section{Ibid., pasim.} 10c. oit.

58" An Act Concerning Louisville," approved Dec. 19, 1795,

59"An Act Concerning the Tom of Louisville," approved Doc. 11, 1801, ibid.

60"An Act Concerning Louis ville," approved Dec. 19, 1795, ibid.

6l"An Act Concerning the Town of Louisville," approved Dec. 11, 1801, 1bid. 
The first Monday in oach month was sot for the rogular board meeting but meotings could be called at other times either by the chairman or on request of two members. ${ }^{62}$ In 1805 the Board roted to fine members for absence fron metings "without good excuse" and this was dono on several occaslons. 63

The actions of the board of trustees included legislative, executive, and to a limited extent, judicial functions. As logislators they enacted ordi nan 008 and by-laws. In the ir executive capacity they appointed administrative of ficers, such as harbor-masters, town sergeant, clerk, treasurer, and others. They likewlse contracted with individuals or groups for munieipal business. No judiclal powers wore rested in them by the Act of 1795, but section 5 of "An act for the more offectual preventing of crimes, conspiracies, and insurrections of Slaves, Free Negroes, and Mulattoes and for their better government" 64 provided "That it shall be lawful for any Trustes of a town to issue his warrant to cause any slave, free negro or mullato, misbehaving within the limits of the town, to be apprehended and brought before him, or some other Trustee of said town, who shall have power to punish.. as is now rested by law In a Justice of the Peace." Apparently tho trustoe was limited in

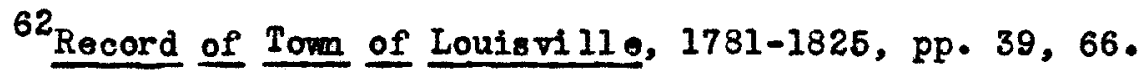
${ }^{63}$ Ibid., passim.

64 Approved Jan. 25, 1811.
} 
jurisdiction to specific cases involving nogros.

The sums of money expended by the trustees during the period were modest, al though they increased almost yearly. The Act of 1795 had I imited the amount of taxes collected to "twenty-five pounds annual ly on the tithable and property, real and personal, within the half-acre lots..." and an additional ximum levy of ten pounds for cleaning out the harbor. ${ }^{65}$ The first annual tax estimate, made in July, 1797, amounted to $31+15 / 6 \mathrm{~d}^{66}$ and the tax rate was set, as follows 67

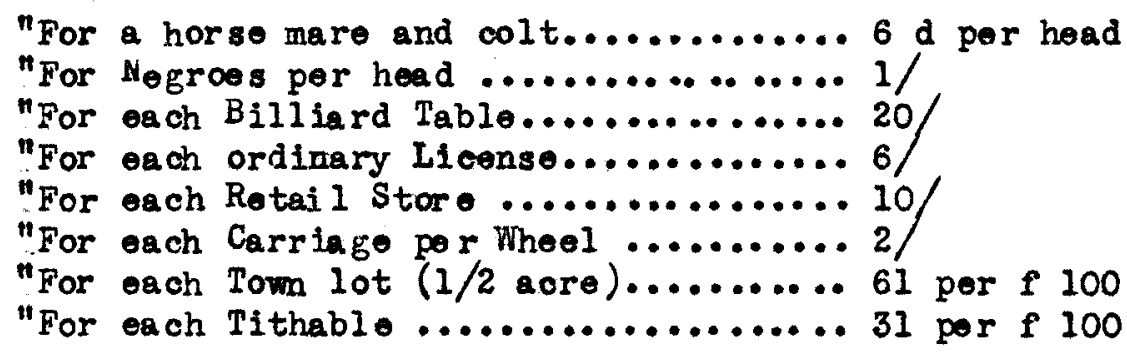

On Fobruary 16, 1802, the Record of Louisville readss

The collector of Tow Taxes having made out his collection Book and it appearing that the Taxes agreeably to the orders of the Board amount to a much greater sum than the Trustees are authorized by law to raise. It is ordered that the Taxes... for the year 1800 and 1801 be reduced ono-half . .

65 "An Act concerning the Tom of Louisvil1e," approved Dec. 19, 1795, Sec. 3, loc. cit.

66n. - the pound of that time equal to Virginia pound of 1777 made oqual by 1 aw to $2 / 3$ of the pound sterling, it was equal to $\$ 3.331 / 3$. The tax, the refore, equaled about $\$ 106$ in our ourrency." (R. T. Durret, "Louis ville Und or the Kontucky Trustees," op. cit., p. 64.)

${ }^{67}$ Record - Town of Louisville, 1781-1827, pp. 39-40, July 3, 
(This is probably the only instance in Louisvillo an record in which the tax rate sat in half.)

In 1803 the legislature increased the levy to $\$ 200$ a year; 68 in 1805 and 1812 taxes were again raised to $\$ 800^{69}$ and $\$ 200^{70}$ a year, respectively. By 1817 the tax revenue was again insufficient to meet the town's needs and in that year the legislature inereased the levy to $\$ 6,000 .^{71}$ The taxes assessed for 1805 amounted to $\$ 237.19 ; 7^{2}$ for $1810, \$ 999.743^{73}$ and for 1821 , the assessment was $\$ 5,996.68 .^{74}$ In 1815 property intended and used for religious worship was declared tax exempt, 75 and in 1825 the legislature empowered the trustees to

- - levy and colloct from each lo inhabitant of said town over the age of twenty-one years, a poll tax not exceeding one

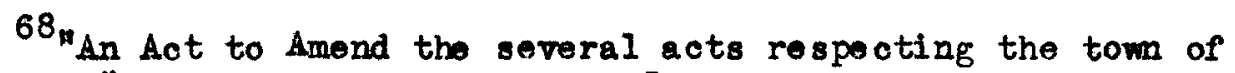
Louisville," approved Dec. 26, 1803, Sec. 3, in Collection of Acts, 1839, pp. 20-21.

69 "An Act to amend the several acts respecting the town of Louisvillo," approred Dec. 21, 1805, Sec. 2, Ibid., p. 21.

$70^{\prime \prime}$ An Act concerning the town of Louisville in Jefferson County," approved Feb. 7, 1812, Sec. 1, ibid., pp. $27 \mathrm{ff}$.

71 "An Act concerning the town of Louisville," approved Jan. 27, 1817, ibid., p. 32 .

$72_{\text {Record }}$ of Town of Louisville, 1781-1825, March 10, 1806, p. 74.

${ }^{73}$ Ibid.

74 Benjamin Casseday. His tory of Louls7ille to 1852, p. 160 .

${ }^{75_{\text {Record }}}$ of Town of Louisville, 1781-1825, Feb. 10, 1815, p. 151. 
dollar; and on real and porsonal property not more than forty cents for every one hundred dollars of the assessed value . .76

\section{Municipal retenues were also augmented somewhat by license} fees and fines. 77 One rather unusurl and questionable method of obtaining revenue is recorded in the minutes of the trustees.

Resolved that William Dougherty be authorized and appointed to take up all Horses, mares, etc. owmed or claimed by a slave or slaves in this town after the 20th Inst. and sell them at public auction in the streets of said town (without advertising) for the best prico that can be ha in ready money and after paying the expense attending the sale, and pay the overplus to the Treasurer of this Board for use of the Town.78

It is a question whether the trustees needed horses or whether the tam needed money.

The municlpal services of Louisville during the first three decades of the nineteenth contury did not keep pace with the rapid growth in population. After the War of 1812, with the opening of the port of New Orleans and the improvement in shipping introduced by the steamboat, Louisville was rapidly outgrowing the trustee type of gorernment. In 1790 the population of Louisville had been $200^{79}$ but by

76 Act granting further powers to the Trustees of the tow of Louisville and for other purposes, Dec. 17, 1825, Sec. 1, in Collection of Acts, 1839 .

$$
\begin{aligned}
& 77_{\text {Record of Town of Louisville, 1bid., passim. }} \\
& 73_{\text {Ibid., p. } 149 \text {, Sept. } 19,1814 \text {. }} \\
& 79 \text { A century of Population Growth from First Census of the United } \\
& \text { States to the Twolfth, 1790-1900, p. } 78 \text {. }
\end{aligned}
$$


the turn of the century it had probably reached $600 .^{80}$ During the next decade the population doubled, and from 1810 to 1820 , it trebled. $^{81}$ By 1827 the inhabitants of Louisville numbered $7,063.82$ Meanwhile the assessment valuation of property had increased from less than a hundred thousand dollars in 1800 to over two hundred thousand in 1810 and to more than one and one-half million in $1820 .^{83}$ Louis ville was a growing commercial tom and its trustees were more concerned with trade than with the living conditions of its inhabitants, al though Louis ville was probably not far behind even the larger localities of that day. ${ }^{84}$ Some of the streets within the city were pared and by 1825 the trustees had obtained authorization for digging a canel. 85 Their chief considerations, however, were fines and fees and trade regulations.

The town had been surveyed in 1780 and again in $1812 .^{86}$ The

${ }^{80}$ Casseday, op. cit., p. 247 ; History of Ohio Falls Cities, Vol. 1, p. 257. The latter source gives population of 1800 as 359. 81 Ibid.

${ }^{82}$ Casseday, op. cit., p. 173; History of Ohio Falls Cities, Vol. 1, p. 257.

${ }^{83}$ Casseday, op. cit., p. 247 .

84 Munro, Government of American Cities, pp. $9 \mathrm{ff}$.

${ }^{85}$ Collins, op. c1t., Vol. 1, p. 37.

${ }^{86}$ Pursuant to enabling act of legislature, approved Feb. 22, 1808 ("An Act to amend the several acts relative to the town of Louisville," Sec. 2.) 
surveys had called for the widening of Main Street and provision for a common. Subsequently, however, this land was divided into lots and sold by the trustees. 87 No provision for public education had been made and poor relief was unsystematic. (The county court annually lovied sums for paupers and left sums with individuals between meetings for relief purposes.) $)^{88}$

Dr. M'Murtrie, writing in 1819, complains of the "bad quality of water in general use" and of the lack of alleys and public squares. 89 It was not unt1 1827 that the Board of Trusteos agrood to pay the expenses of a fire company. 90 The first "police force" was established In 1810 on petition of the citizens; this consisted of two watchmen, 91 at a salary of $\$ 250$ a year, whose duties were to "patrol the streets from ten p.m. until daybreak, to cry the hour and weather, to hold. in the watch-house any person out wi thout reason after ten o'clock to

87M'Murtrie, Henry, Sketches of Louisville, 1819, p. 113.

88

Kentucky Lews, 1797, Part VIII - Laws Establishing courts of Justice, 4 reads in part "They (the county courts) establish and regulate ferries and provide for their poor" passed Dec. 17, 1796; Dr. M'Murtrie deplores the lack of better provision for the poor but offers as possible reason, the virtual absence of paupers in Louisvillo (pp. 144-145).

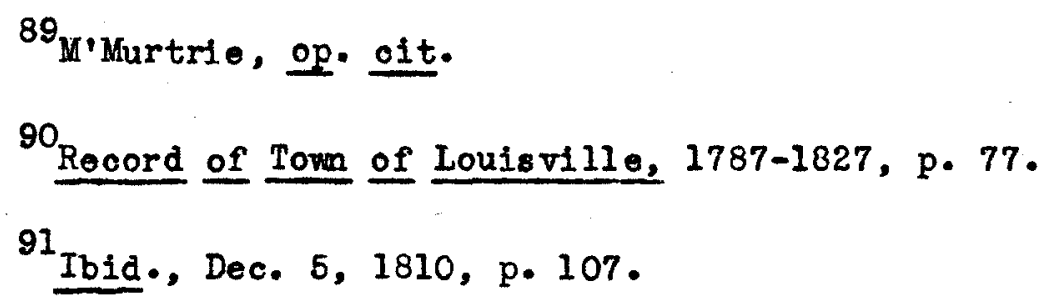


prevent conflagrations, Felonies, Riots, routs, breaches of the peace and all unlawful assemblages of ne groes. ${ }^{n 2}$

How efficiently two watchmen were able to patrol even this small community may be shown by again quoting Dr. M'Murtrie:

A watchman is a character perfectly unknown and not a single lamp lends its cheering light to the nocturnal passenger, who consequently stands a very good chance of breaking his neck by falling into ditches, drains, and wells, wich without a barrior of any kind around thom, a re frequently 1 eft open for weeks and even months together. To show the necessity of a radical reform in the police of this place, much more might be added but, as the subject more particularly interests those whose senses daily give them a thousand unequivocal proofs of the fact. I shall conclude by hinting to the $m$, that it must always be thus until they have of ficers appointed by the people whose whole and sole duty it is to look after these things, and who are paid for it, or in other words, until the procure an act of incorporation. As lone as the trustees or other officers are chosen from among mercantile men, who have no o ther inducement to leave their own business for that of another, but the public good, so long will the town have to take care of itself. Verbum sapienti. 93

Dr. M'Murtrie was not al one in this viewpoint. On November 3, 1827, a meoting of the citizens of Louis ville was held to consider incorporation and five resolutions were adopted requesting that a committeo of seven citizens be empowered to draw up a charter to be submitted to the legislature. The two outlying commities, Shippingport and Portland were asked to join; the former accepted, but Portland

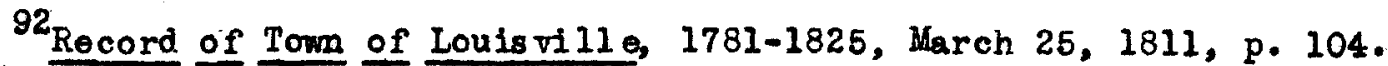
93 M'Murtrie, op. cit., pp. 143-144. 
remained a separate town 94 until 1852.95

The citizens resolutions were presented to the logislature in 1828 and the charter of incorporation, apparently without having been submitted to the people of Louisville, passed February 13, 1829.

${ }^{94}$ Casseday, op. cit., p. 172 .

95 An Act to Provide for the Annoxation of the Town of Portland to the City of Louis ville, approved Jan. 9, 1852, Sec. 1. 


\section{CHAPTER II}

\section{LOUISVILLE UNDER THE FIRST CHARTER}

\section{$1828-1850$}

The history of Louis ville from 1828 to 1850 is characterized by significant economic growth and development. By 1830 Louis ville with a population of 10,341 had gained the prestige of being the largest town in the State; by 1850 her populati on had reached 43,194 ! Situated strategically for trade botween Pittsburgh and Now Orleans, the city shared in the commerclal prosperity and devolopment of the Mississippi Val loy. The Portland Canal, first projected some twentyseven years earlier, ${ }^{2}$ was finally opened to trade in $1831^{3}$ and by 1845 over three million tons of freight had passed through it. 4 The first railrcad ontering Louisville, section of the Lexington and Ohio Railroad, was in operation between Sixth Street and Portland in 1838.5 Commerce, as it had been since earliest days, continued to

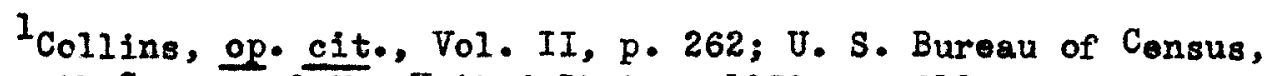
The Seventh Census of the United States, 1850, p. 612 .

In 1804 a company had been incorporated by the State legislature to cut a canal, but only surveys were made at that time.

${ }^{3}$ Otis, op. cit., p. 114.

${ }^{4}$ American Democrat and Weekly Courier, Feb. 4, 1846.

${ }^{5}$ Collins, op. cit., Vol. II, p. 358 . 
be the city's chlef enterprise, while after 1840 manufacturing showed substantial growth.

The 1828 charter reflected, in general, the trend and thought of the times, embodying as it did the idea that the purposes of government were primarily the protection and regulation of property and the conduct of such public enterprises as the construction of streots, the operation of ferries, establishment of markets and the likes only secondary importance was attached to such functions as health, education and welfare. The structure of the municipal government introduced no radical changes but was rather an outgrowth of the older form. Under the charter the power of governing the city was vested in a mayc and council instead of trusteos. Although the council's jurisdiction was somewhat broader and the powers granted them by the legislature were more general than those of their predecessors, the governing power continued to reside within a comparatively small group of men chosen by rote of an electorate composed principally of propertyowners. Nevertheless, the legislature, evidently considered the charter an experiment, 6 for they decreed that it should remain in effect for a period of five years only; an act of continuance passed in

6altimoro's first act of incorporation (1797) was also considered an experiment and mede effective for one year only; the next session of the assembly, however, made it perpetual. See T. P. Thomas, "The City Government of Baltimore," Baltimore, 1896 (Johns-Hopkins University Studies in Historical and Political Science, Vol. XIV, No.. 2), p. 58 . 
GENBRAL STRUCTURE

CHARTER OF is28

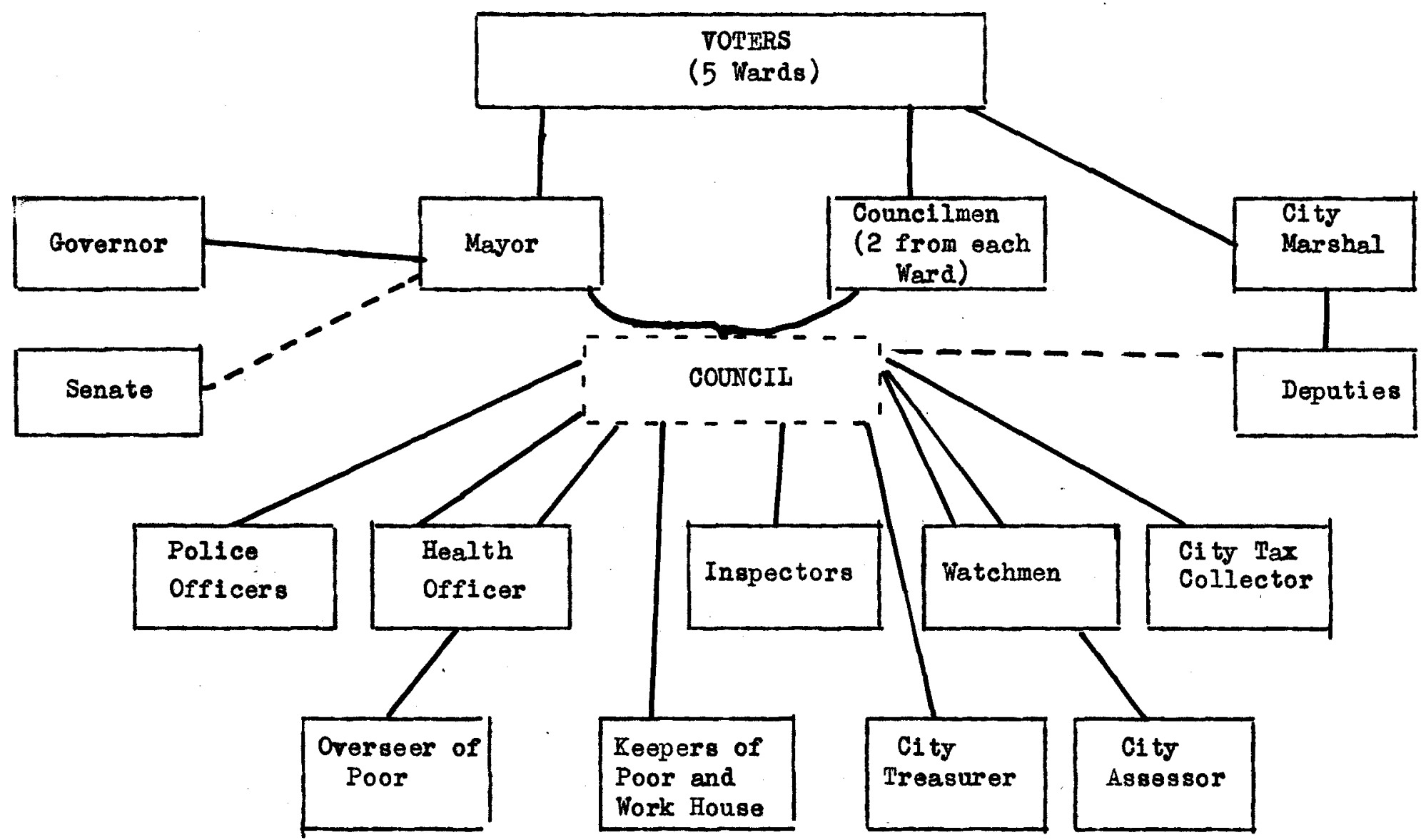


1833, however, extend ed the life of the act indefinitely.?

\author{
Elections and Voting \\ $1828-1850$
}

While the principle of popular election of state and local officials was gaining adherents throughout the country and Kentucky in the constitution of 1799 had changed the mode of electing its governor and senators from electoral to popular vote, 8 the makers of the 1828 charter were still loathe to leave th choice of mayor entirely to the whim of the local electorate. The charter contained the rather unusual provisi on that

- - In all elections for mayor, not less than two persons 10 shall be voted for as such, and the two persons having the highest number of rotes shall . . . be certified to the Governor of this Commonwealth - . stating in the certificate the number of votes given to each, one of whom shall be commissioned by the Governor as Mayor of the City of Louisville, and submitted for

\title{
${ }^{7}$ Charter of 1828 , Sec. 26, Collection of Acts, 1839; Act to
} amend and continue in force an act to incorporate the City of Louisville, Feb. I, 1833; Acts of the General Assembly, 1833, Ch. 204, Sec. 1.

\section{${ }^{8}$ Constitution of Kentudxy, 1799, Art. II, Sec. 8 .}

9 Another instance where state and iocal authorities shared in the selection of the mayor was the eity of Pittsburgh where prior to 1834 the select and common councils together chose the mayor, by electing one of twelve "aldermen," appointed by the governor of the state (McLaughlin and Hart, Cyclopedia of Ame rican Government, Vol. 2, p. 694.)

10 The charter is ambiguous on this point. Cf. Sec. 4, and Sec. 9. 
the advice and consent of the Senate as in other cases...11

It further provided that should the Governor, or the Senate, for sufficient cause, be unwilling to cormis si on eithe $r$ of the voters' choices that this fact

- - be certified by the Secretary of State to the City Council of Louisville, who shall, in not less than ten days or more than thirty days, cause another election to be held for Mayor, to be conducted as other elections are directed to be by this act, and the two persons having the highest number of votes shall be certified to the Governor, who shall commission one of them as aforesaid ... 12

Five yoars later the State legislature took a further precaution to insure state control by decrooing that in the ovent that only one person be chosen by the voters of Louis ville, the Mayor and council were to

- . recommend to the Governor some other competent and qualified person to act as Mayor 3 one of whom the Governor shall - $\because$ comission as Mayor ... I

This same act also reperled the clause necessitating a second election should the Gorernor be dissatisfied with both men recommended, and instead empowered the yor and council to select two other qualified persons. 14

It so happened, however, that whaterer the intention of the

11

Charter of 1828 , 100. oit.

12 Charter of 1828 , loc. eit., Sec. 24.

13

Amend., Feb. 1, 1833, Sec. 3, 100. c1t.

${ }^{14}$ Ibid. 
legislature, state control of the choice of the Mayor of Louisville oxisted merely on the statute books. In proctice, in every eloction on record from 1829 through 1835, the candidate recoiving the greatest number of rotes was commis si oned mayor. ${ }^{15}$ Furthermore, inasmuch as municipal elections were held in March ${ }^{16}$ and the state legislature was in session regularly only during January and February, ${ }^{17}$ the confirmation of the governor's appointment by that body was holly without meaning -- the mayor had already held offlce for ten months of his twolvemonths' term.

In 1836 the power of the selection of the mayor was finally taken out of the hands of the governor and sonate and granted to the city council. It was prescribed that

- . It shall be the duty of the City Council of Louisville . . to elect some competent person as Mayor of said city . . and the majority of the number of councilmen shall concur in such election..18

This proved a most unsatisfactory method of choosing a mayor, since often no nominee could obtain a necessary majority. In the first oloction by the council, a deadlock continued for three consecutive

\footnotetext{
${ }^{15}$ City Journal, March 11,1828 - Juno 29,1835 , vols . 1-4, passim.
}

${ }^{16}$ Charter of 1828 , Sec. 2 .

17 Acts of the General Assembly, 1833, Ch. 91 .

${ }^{18}$ Acts of the General As sembly, Ch. 257, Sec. 18, p. 284 . 
meetings. 19 At the second meting a resolution was introduced proposing that the election be referred to the people, "the original and legitimate source of all political power" and that the council vote unanimously for the candidate who should recoive the greatest number of votes. 20 The motion lost by a vote of 3 to 7 (The only two mayoral candidates anong the councilmen voted in favor of the resolution). Later, after numerous ineffectual ballotings, the resolution was reconsidered, this tim the vote being tied 5 to 5.21 Finally at a third meting, after many more ballotings, William A. Cocko was elected mayor. 22 In the election of 1837 , the rote was taken thirteen times before Frederiok A. Kaye was declared mayor elect. 23

There is no doubt that the citizens of the city ware displeased with the council method of election. The following petition to the state legislature selrculated throughout the community and receired the endorsement of at least one newspapers 24

${ }^{19}$ City Journal, vol. 6, March 7, 1836, p. 268; March 14, 1836, pp. 277-278; March 21, 1836, p. 288.

${ }^{23}$ City Journal, vol. 7 , March 15,1837, p. 125.

24The Louigville Daily Journa 1, editorial, Dec. 19, 1836. 
The undersigned citizens of Louls ville, pray your honorable body so to alter the Charter of said city as to give the eloction of the mayor directly to the people, instead of leaving that office to be fllled, as at present, by the City Council. They believe that the mayor ought to be elected by the legal roters, who are now recognized in the city Charter as having the right to vote for councilmon. They also pray that the mayor, instead of being elected for one year, may be elected for two years, and then he may be ineligible for the next two years...

The state legislature, apparently cognizant of the will of the local eloctorate passed an aot amending the charter in 1838. Following the lead of other state legislatures, 25 it provided that the mayor should be elected by the qualifled voters of the city. 26

From this time on until the adoption of the new charter in 1851 , with one exception, eleotions were conducted in routine manner. The one exception was the contested election in 184l. The contest arose between William A. Cocke, who received the majority rote, and James Harrison. The latter presented a momorial alleging various reasons why $\mathrm{Mr}$. Cocke should not take office as mayor. 27 In response Cocke requested a new election. A second election ${ }^{28}$ was held and the rote

25 Charters adopted between 1820 and 1835 in the cities of Boston, St. Louis, Detroit, Philadelphia, Baltimore, and New York, all provided for election of mayor by popular vote. Seo Fairlio, Municipal Administration. pp. 81-82.

26 An Act to amend the charter of the City of Louisville, approved Jen. 16, 1838, Sec. 3, in Elliott, op. cit., p. 75.

27 The Louisville Daily Journal, May 7, 1841; City Journal, vol. 9, May $6, \frac{1841, \mathrm{p} \cdot 307}{\mathrm{ff} \text {. }}$

${ }^{28}$ The electi ons of councilmon from two wards were likewise under attack. Se日 City Journa 1, May 6, 1841 . 
this time wont to a third candidate, David L. Beatty, with a plurality of 135 votes over the number received by James Harrison. 29

Vacancies in the mayor's office were filled by a member of the city council, chosen by that body, pending the outcome of a new election held in the or iginal manner of el ecting a mayor. ${ }^{30}$ An amendment to the charter, passed in 1838 , stated that should the office of mor be vacated, a successor for the unexpired term was to be elected by the council. 31 In the event of a racancy, for whatever cause, in the office of councilman the law provided that

- - the Mayor and residuo of the councilmen shall, forthwith, supply the vacancy by the election of some other qualified resident of the ward...32

From the date of Louisville's incorporatl on, councilmen were elected by popular vote ${ }^{33}$ and, until 1836 , the office of city marshal was elective. 34 Thereafter the marshal was appointed annually by the mayor with "the advice and consent of a majority of the council." 35

${ }^{29_{\text {City Journal, }}}$ vol. 9, May 17, 1841, p. 315.

30 Charter of 1828 , Sec. 15,100 eit.; Acts of the General Assembly, 1836, Ch. 257, Sec. 18 (p. $\overline{284})$.

${ }^{31}$ Amend., Jan. 16,1838, Sec. 3, loc. cit., p. 75.

32 Amend., Doo. 23, 1831. Acts of the General Assembly, 1831, ch. 746, Soo. 5 (p. 199$)$.

${ }^{33}$ Charter of 1828 , Seo.

${ }^{34}$ Ibid.

$35_{\text {Acts }}$ of the General Assembly, ch. 257, Sec. 10 (p. 282). 
The city, according to charter provision, was divided into fivo wards, each of wich elected by popular vote, two councilmen. 36 The mayor and council were charged with the responsibility of redistricting wards from time to time in order to equalize the number of inhabitants. 37 The number of wards was increased to 8 ix in $1836 .^{38}$ Two years later the council sagain increased, this timo to sixteen members, with the passage of a charter amendment dividing the city into eight wards. The same amendment also specified

That in the year 1840 and overy five yoars thereafter, the counoil shall divide the city into eight wards, as nearly equal in population and roters as may be; and for that purpose, previous to any such division, it shall cause a consus of the population and roters in cach rard to be taken... 39

The trend during the first half of the ninoteenth century was toward a widening of suffrage. Tax-paying and property-holding qualifications, imposed by most states prior to $1830,{ }^{40}$ were being abolished in the wake of Jacksonian democracy which was sweeping the country. In Kontucky the franchise had boen extended since 1799 to overy froe, white, male citizen who had attained the age of twenty-one and who had resided within the state two years or within the locality in which he

${ }^{36}$ Charter of 1828 , Sec. 3, 10c. eit.

37 Ibid.

${ }^{38}$ Acts of the General Assembly, ch. 257, Sec. 17. (p. 284).

${ }^{39}$ Amend., Jan. 16, 1838, Sec. 11, 10c. cit., p. 77.

${ }^{40}$ Munro, Government of American Cities, p. 11 . 
was roting one year. ${ }^{41}$ The Louis ville charter of 1828 limited the vote to citizens who had lived in the city for at least six months ${ }^{42}$ Later, residence in the ward in which on voted was required, 43 and in 1838 the requisite length of residence within the city was extended to one year. 44

Besides certain rosidence requirements, tax-paying qualifications were imposed. No person was eligible to rote who had not "been assessed and paid taxes for the preceding year."45 An amendment passed in 1838 required payment of taxes at least twenty days previous to eloction. 46

While there had been virtually no change in voting qualifica-

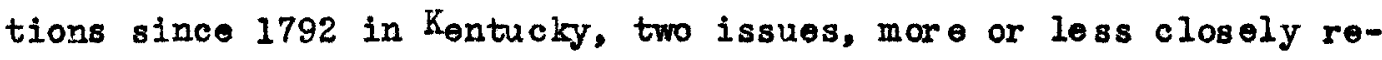
lated to suffrage arose about this time and were heatedly debated in the press and elsewhere. Ono of these issus was resolved in the convention debates of 1849 and its outcome legalized in the State Constitution of 1850. The second became a major issue in the adoption

\section{1} Kontucky Constitution of 1799, Art. II, Sec. 8 . ${ }^{42}$ Charter of 1828 , Sec. 4, 10c. cit.

43 Acts of the General Assembly, 1836, Ch. 257, Sec. 17 .

44 An Act to amend the Charter of the City of Louisville, approved Jan. 16, 1838, Sec. 13 .

45 Acts of the General Assembly, 1831, Ch. 746, Sec. 14. There is no mention of taxpaying qualifioation in the charter of 1828.

${ }^{46}$ An Act to amend the Charter of the City of Louisville, approved Jan. 16, 1838, Sec. 13, 10c. cit. 
of the new Louis ville charter of 1851.

The first issue on the subject of suffrage arose with the influx of foreigners into the United States during the third and fourth decades of the century. Two states ${ }^{47}$ had already permitted unnaturalized foreigners to vote. In Kentucky the controversy became a verbal battlo waged in the nowspapers and on the floor of the Constitutional Convention of 1849 , but the 1851 Constitution was drawn up without extending the franchise to unnaturalized foreigners.

The second is sue, more specifically related to municipal gorernment, was the tax-paying qual ification for voting in municipal elections. The question arose whether the provision of the constitution declaring that "all elections should be free and equal"48 prohibited the tax-paying qualification. The traditional tax-payer viewpoint is expressed in an editorial appoaring in the Daily Journal:

- - In a local government like that of a city instituted merely for the purpose of regulating property and to raise a revenue for its improvement and protection, to allow a man, who neither has property nor pays a tax, to have an oqual voice with him who has property and pays a tax in saying how the property shall be improved and protected, would be to establish a mode of election, which instead of being equal, would be grossly unequal and wi thout any basis of fairness or justice...49

47 Miohigan and Illinois. Illinois enfranchised all white male inhabitants twenty-one years of age or above, who had resided in the state $s i x$ months. See Kneir, City Government in the United States, p. 167 .

${ }^{48}$ Kentucky Constitution of 1799, Art. X, Sec. 5 .

${ }^{49}$ Louisvilie Daily Journal, January 25, 1837. 
This view was challenged by the proponents of the new charter of 1851 who rejected "property as the base representation" and denied it "as a qualification for the voter."50 Nor was popular reaction against the tax-paying qualification for roting unique in Louisville. In St. Louis, for instaneo, it was maintained by some that the municipal oloction of 1844 was carried by the dog-tax. Citizens who had never owned a dog qualified as voters by paying a dog tax. 51

It is difficult to ascertain the oxtent to which national party politics entered into the municipal elections of this period. It is, how over, reasonable to assume from the oditorials and other articles in newspapers of varying political views, that al though party lines were not wholly disregarded, 1 ocal issues were the determining factor. 52 It is also true that inasmuch as municipal elections were held in the spring, and state and national elections, in the fall, time separated the issues of the city from those of state and nation.

Elections were hold the first Monday in March ${ }^{53}$ under regulations made by the council. The council furnished lists of those who

${ }^{50}$ Louisville Dai ly Democrat, Fөb. 17, 1851.

51M. S. Snow, "The City Government of St. Louis" (Johns Hopkins University Studies in Histarical and Political Science. Fifth Series, No. IV, Apr. 1887), pp. 14-15.

52 Louisville Daily Journal, May 14, 1841, editorial; Louisville Public Advertiser, $1840-1844$, passim.

53

Charter of 1828 , Sec. 4 , 10c. cit. 
had bees assessed and had paid taxes for the preceding year. 54 In each ward, elections were conducted und or the auspices of three inspectors, appointed by the council. The authority to determine the validity of election results was a prerugatire of the council, who had tre power to declare an election void and order a now one or to award the election to the candidate with the second highest number of votes. Expenses of all elections -- municipal, state, and congressional -- held within the city were borne by the city treasury. 55

While the first State Constitution had called for ballots for all elections, 56 this had boon changed in 1799. An act on elections passed in that year provided that

- The persons entitled to suffrage shall in the presence of - - judges and sheriff, vote personal ly and publicly, viva roce . . .57

The abuses of this method of roting are obvious and public voting did not go unchallenged by the local press of that period. The Journal complained that

- Elections instead of being decided by suffrage, are carried by bank notes, and the corruption is as much known and recognized at the polls, as if it formed a part of the consti-

(p. 199). ${ }^{54}$ Ibid.; Acts of the General Assembly, 1831, Ch. 746, Soc. 4.,

55 Amend., Feb. 1, 1833, Acts of the General Assembly, 1833, Ch. 204, Sec. 3 .

${ }^{56}$ Constitution of $K_{\text {entu cky, }} 1792$, Art. III, Sec. 2 .

57 Wm. Iittel 1, Digest of Statutes of Kentucky, Frankfort, Ky•, 1822, Ch. LXIII, Sec. 3 . 
tutional provisions for qualifying voters...58

and the Examiner, pointing out such evils of the system as the hiring of bullies and bribing, strongly adrocated the adoption of the ballot. 59 Election reform was sorely needed, for the way was being paved for the election riots of later years.

The Mayor and Council

To be elected mayor or councilman of Louisville under the origInal act of incorporation it was only necessary for the aspirant to be a citizen of the Commonwealth of Kentacky and a resident of Louisville for two years. 60 Although it is doubtful whether, at that time, any person other than a property-owner would have run for office, and less likely that, had he run, he would have been elected, there no written property qualification in the charter. Three years later, however, qualifioations were so amended that no person was eligible for elective office who not a "housekeeper or freeholder" and who had not paid taxes within the city for the preceding year. A councilman was also required to reside in the ward from which he was elected and to resign his office should he move from that ward during his term of

${ }^{58}$ Louisville (Wookly) Journal, Oct. 4, 1839, editorial.

59 $9_{\text {The Examiner, Aug }} 18,1849$, Sept. 22, 1849, and passim.

60

Charter of 1828, Sec. 2., loc. cit. 
office. 61 In 1838 qualifications for el ective of fices were again revised. An act to amend the charter provided

That no person shall be eligible as a member of the council - - who is not of the age of twenty-five years; who is not a resident of the ward electing him; who has not resided in the city three years next precedin the el oction; who is not a freeholder, or housekeeper with a family, and who shall not have paid his city taxes at least twenty days previous to the election...62

The same act prohibited the mayor and members of the councll from retaining their seats on the council upon becoming candidates for state or federal legis lature 63 and also provid ed

That neither the mayor or any member of the council shall, directly or indirectly, be interested in any contract with the city. .64

Between 1838 and 1850 no further changes were made in qualifications.

Members of the council served wi thout pay. The mayor's salary was fixed in his absence by the board of councilmen and could not be changed during his term of office. 65 The salary actual ly paid was $\$ 600$ annually, ${ }^{66}$ excluding fees, ${ }^{67}$ until 1836 when it was increased

61 Amend., Dec. 23, 1831, Sec. 5, Acts of the General Assembly, 1831, Ch. 746, Sec. 5, (p. 200).

62 An Act to amend the Charter of the City of Louisville, approved Jan. 16, 1838, Sec. 4, in Elliott, op. cit., p. 75.

63 Ibid., Sec. 5 .

${ }^{64}$ Amend., Jan. 16,1838 , Sec. 8, loc. cit., pp. 76-77.

${ }^{65}$ Charter of 1828 , Sec. 6, loc. cit.

${ }^{66}$ City Journal, Vols. 2-6, passim.

${ }^{67}$ Charter of 1828 , Sec. 6 , 1oc. cit. 
68

by statute to a minimum of $\$ 2,000$ a year.

Councilmen throughout the period, and the mayor until 1837, served for one year only. 69 Reelection, however, was not uncommon, and during this period only three mayors held office. 70 In 1837 a charter amendment extend ed the mayor's term of office to three years and prohibited the incumbent from succeedin himself in of fice. 71

The mayor and board of councilmen sat as one body and their meetings were open to the public. The mayor convened the board as often as he deemed advisable and presided at its meotings. He cast his vote only in case of tie, and had no power of veto. His chief influence with in the council $l$ ay in his advisory powers for it was his responsibility to "recommend all such measures as may tend to the improvement of finances, the police, health, security, cleanliness, comfort, and ornament" of the city ${ }^{72}$

A carry-over from the trustee type of government, certein judicial powers were accorded the mayor, and for a few years he retained these powers. The charter of 1828 bestowed on him Sec. 18 .

${ }^{68}$ Amend., Feb. 25, 1826, Aots of the General Assembly, Ch. 257,

${ }^{69}$ Charter of 1828, Soc. 2, loc. cit.

70 John C. Bucklin, $1828-1833$; Jams Joyes, 1834-1835; William A. Cocke, 1836 .

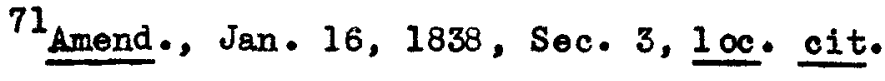

${ }^{72}$ Charter of 1828 , Sec. 6, loc. cit.
} 
the power of justice of the peace of the county of Jefferson over slaves and free nogroes, and the power of justice of the peace to require surety for good beharior, and for the peace, and in all matters of penalties far a violation of the laws of this commonwealth and the ordinances of the city council, and as to committing criminal offenders and sending them on for trial, he shall have the powers of two justices of the peace, but shall not have or exercise any judicial authority in civil matters. 73

In 1833 the mayor's judicial powers were broadened. He was given the power to adjudicate all cases involving breach of the penal laws of the state which arose within the $c$ it $y^{74}$ and he was also granted the power

to bind out orphan chlldren of persons who are not able, or from their habits and character, are not likely to bring them up in honest courses . - and the like power to hear and determine the complaints of apprentices bound out by him... and he may contract for additional advantages in favor of apprentices bound out by him. 75

Along with the wider jurisdiction this act granted, it also enabled the mayor and council to select one or two magistrates of Jefferson County to preside with the mayor in court and in the mayor's absence to discharge his duties. 76 It gave the mayor's court the same authority within the city of Louisville as was accorded the Jefferson

\section{${ }^{73}$ Ibid.}

74 An Act to amend and continue in force An Act to incorporate the City of Louis ville, approved Feb. I, 1833, Sec. 19, Acts of the General Assembly, 1833, Ch. 204, Sec. 19.

$$
\begin{aligned}
& { }^{75} \text { Ibid., Sec. } 7 . \\
& { }^{76} \text { Ibid., Sec. } 10 .
\end{aligned}
$$


circuit court in issuing warrants and determining cases involving riots, unlawful assemblages, or breach of the peace, ${ }^{77}$ and reaffirmed the myor's authority over negroes and mullatoes in Lou isville, equalizing his authority th that vested in the justices of the peace and the county courts.

In 1836 the mayor's judici al authority, wich had never extended to civil matters, was terminated by the passage of An Act to establish a Police Court in Louisville and to amend the Charter of said City. This act abolished the Mayor's Court and provided for the establishment in its stead of a police court under a single judge appointed in the same manner as other state judicial officers, wi th jurisdiction concurrent with the Jefferson Circuit Court. 79

The mayor was the executive officer of the city and as such was responsible for the execution of all laws and conduct of all subordinate officers. Yet, al though he was author iz ed to have "all negligence, carelessness, and positive violation of duty . . duly prosecuted and punished," 80 his executive power was decidedly limited, for he had neither the power of appointing nor the power of dismissing

\footnotetext{
77 Amend., Feb. 1, 1833, Sec. 8, loc. cit.

${ }^{78}$ Ib1d., Sec. 9.
}

79 An Act to establish a Police Court in Louisville and to amend the Charter of said City, approved Feb. 22, 1836, Acts of the General Assembly, 1836, Ch. 257, Sec8. 1, 2 .

${ }^{80}$ Charter of 1828 , Sec. $6,10 c$. cit. 
city officials. Subordinate officers, such as the city treasurer, police officers, assessors, keepers of the poor and work house, and others, were appointed by the mayor and councilmen. 81 It should be remembered that the mayor could vote only in case of tie, 82 and that his only recorse in the event of glect of duty on the part of subordinate officials was prosecution in court. 83

Responsibility for efficient adninistration was somewat more definitely allocated by the passage of an amendment in 1836 whereby the mayor was granted power of removal of all officers connected directly with police and health. These of flcers received their appointments through nominati on by the mayor and confirmation by the council. 84 All other city officials were elected annually by the. mayor and council and were subject to removal by a majority of the council. These of ficers -- the city clerk, treasurer and collectors, attorney, wharf-master, market master, trusteos of the public schools, keeper of the poor and work house, sexton of the graveyards, and other minor officials -- were likewise under the supervision of the mayor, who could make known to the council a ny breach or neglect of duty. 85

${ }^{81}$ Charter of 1828 , Secs. 11 and 17.

${ }^{82}$ Supre, p. 45, footnote 72 .

${ }^{83}$ Supra, p. 47 , footnote 80 .

84 Amend., Feb. 22, 1836, Acts of the General Assembly, 1836, Ch. 257, Sec. 20 .

${ }^{85}$ Ib\&d. 
With few exceptions city of ficials were elected annually. The record of the yor and councilmen shor that reap pointments were rathor frequent throughout the period from 1828 to 1850 . For example in 1836, in the year of the election of a new mayor, out of eight of the appointments of the more important city of ficials, three were reappointments. 86 In 1841, also a mayoral el ection year, there were four reappointments among ei ght of the city officials elected by the council. 87 Most city officials held their positions more than one year, and som for several years. The same city marshal held office from 1832 to 1849 , elected annually by the voters during the first four years, and the reafter appointed by the mayor and council. 88

The council appointed the majority of the city officials, and, for the most part, the power of remoral, also, belonged to that body. The power of the council to remove any of its own membership or the mayor from office was authorized by a charter amendment:

- - the council, nine members concurring (after then days' previous notice) may expel any of its own body or remove the mayor from office, the reason the refor being spread on its journal. 89

Likewise it was the responsibility of the council to remove the

${ }^{86}$ City Journal, Vol. 6, May 20, i836, p. 359.

${ }^{87}$ City Journal, Vol. 9, May 24, 1841, p. 331.

${ }^{88}$ City Journal, Vols. 3-9, passim.

${ }^{89}$ Ibid., Sec. 6. 
mayor from office should he

- . by improper inter ferene wi th a ny city, state, or national election, attempt to control or influence the votes of another - - the 7 members [of the council] determining what is or is not such an improper interference with an election . . 90

Most powers and responsibilities belonged to the mayor and council jointly, but certain duties fell to the mayor alone. Fire control was one of the most important municipal functions in that time of horse-dram rehicles and city pumps, and it was beholden upon the mayor to be present at all fires. He was likewise "visitor of the public schools."91 He supervised the wharres and market houses of the city and with the consent of the council, made all contracts for municipal improvem ent s. 92

The charter bestored on the may or and councilmen in general

- - all the powers and authority heretofore vested in the trustees of Louisville - . with power and authori ty to adopt the by-laws and ordinances of said town, and the same to repeal, alter, and amend, as to them shall seem best, and with full power and authority to pass such by-laws and ordinances, with adequate penalties, as they shall from time to time deem expedient for the government of said city...93

and granted them specifically the following powers:

1. To open new streots and al leys, to keep streets and al leys open,

90

Ibid., Sec. 3.

91 Amend., Feb. 22, 1836, Sec. 19, 10c. cit.

$92_{\text {Ibid., Sec. } 19 .}$

${ }^{93}$ Charter of 1828 , Soc. 7 . 
and to have sidewalks pared. 94

2. To purchase, hold, and sell real estate within the city, and to purchase, hold, and sell personal property and stock in incorporated companies.

3. To borrow money on the credit of the corporation.

4. To appoint inspectors of flour, tobacco, whiskey, beef and pork, and others.

5. To appoint a health officer, to pass regulations necessary to prevent the introduction of smallpox, and to eradicate such disease in opldemic.

6. To organize a fire departmont.

7. To prohibit the erection of wooden bulldings, to regulate height and size of buildings, etc.

8. To erect or procure suitable building for work and poor house.

9. To assess, levy, and collect taxes "on such real estate as they may designate in that part of the city, wich composes the present town of Louisville, to the Third cross street of Preston's enlargement; 95 but such taxation shall be uniform on every description of property assessed."

10. To levy a poll tax on each free ma lo of twenty-one and upwards, except paupers, and on all slaves over sixteen.

${ }^{94}$ Ibid., Sec. 8.

95 Boundaries of city and boundaries for taxation purposes did not coincide until passage of Charter of 1852, Sec. 12; ad valorem tax limit was forty cents on $\$ 100$. 
11. To license and tax taverns, grocers, etc., and to license theatricals and shows. (The yor was expressly forbidden by law to revoke a license.) 96

12. To erect or procure suitable buildings as poxder magazines, provide for conveyance of gunpowder, and to pass by-laws prohibiting introduction of gunpowder into the city .

13. To establish one or more free schools in each ward, to erect necessary buildings, and to provide necessary revenue for maintenance, and to levy a tax for school purposes on the ward where such schools may be established. 97

14. To pass necessary by-laws with adequate penalties for their infraction, not exceeding fifty dollars "which penalties may be sued for in the name of the city and recovered before any Justice of the Peace." 98

15. To purchase one or two pieces of property not exceeding fifty acres each outside the city to be used for burial grounds. 99 It was mandatory that all by laws and ordinances passed by the mayor and council be recorded in the journal of their proceedings and

\footnotetext{
96 Amend., Jan. 16, 1838, Sec. 3, 10c. eit.

97 Charter of 1828 , Sec. 11 .

${ }^{98}$ Ibid., Sec. 18.

Ch. 204, S9ec. 5. Fob. 1, 1833, Acts of the General Assembly, 1833,
} 
publishod. 100

The original act of incorporation provided that

- - In all meetings of the board, five councilmen, with the mayor, or in the absence of the mayor, six councilmen, shall constitute a quorum to do business, except in the cases of brying the taxes or the election of any of ficer of the city government, in which cases at least eight councilmen shal 1 bo present, and not less than fivo vote in the affirmative... 101

The council conducted its affairs through standing conmittees and the number of these cormittees inereased as the functions of the municipality expanded. In 1833 there were but three permanent committees of the councils Committee of Finance, Committee of the Poor, and Committee of Street Comissionery 102 By 1839 there were eight, concerned with Finance, Streets, wharf, coffee-houses, public works, wor $\mathbf{k}$ house, fire department, and revision. These comittees consisted of three members each, and were appointed by the mayor at the first regular meeting of the counci 1. They had general superintendence of their various departments and made monthly reports to the mayor and council. 103

The council fixed the salaries of most of the city officials, approved contracts for the parement and repair of streets, bridges,

\footnotetext{
100 Charter of 1828 , Sec. 14 .

101 Charter of 1828 , Sec. 6, loc. cit.

${ }^{102}$ City Journal, Vol. 4, Marah 11, 1833. Acts, 1839 .

${ }^{103}$ City Ordinances, 1839 , Nos. 32 and 33 , in Collection of
} 
and other improvements, passed fire regulations, issued licenses, set the price of hire of hacks, regulated markets and wharves, provided for welfare -- in short, all municipal activities were carried out by the council or by a committee of the council. ${ }^{104}$ All expenditures from $\$ 6.00$ for four loads of wood for the poor house" 105 to $\$ 20,000$ for the purchase of "a wharf, warehouse and ferry"106 were passed on by the council.

Before 1830 there had been no attempt made to budget the city's revenue. Payments were nearly always ordered "out of any money not otherwise appropriated." Mayor Bucklin in his opening address to the council in 1830 estimated the probable expenditures for the year 107 and from this time on it became customary for the mayor to present a statement of the city's financial status and probable expenditures for the coming year, as well as to make recommendations. ${ }^{108}$

The council was little concerned with most of the municipal serVices which are foremost today. Provision for health and welfare continued haphazard throughout the period. From time to time a board of health was established by ordinance, ${ }^{109}$ but such a board was without

${ }^{104}$ Ci ty Journal, Vols. 1-14, passim.

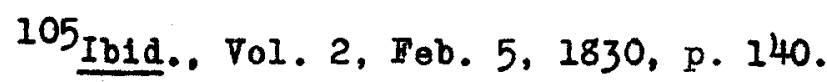

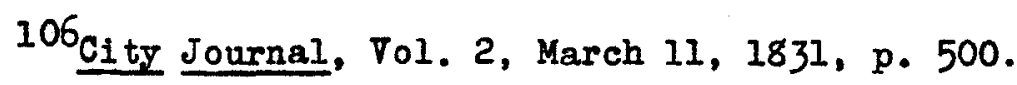

107 Ibid., March 12, 1830, pp. 187-188.

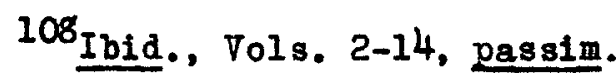

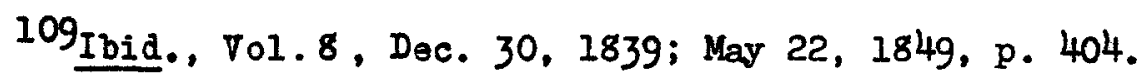


the implication it would have today and concern for health was genorally limited to periods of epidemic. 110 Poor relief was under the direct supervision of the council. Individual hardship cases were brought to the attention of the council far action, or, as happened from time to time, the councilmen appropriated a sum of money to be placed in the hands of somo designated individual for care of the needy. 111

Fire control was rested in independent companies subject to such regulations as the council impos ed. 112 The first street lights were provided by contract with the Gas and Water. Company in 1839.113 Although as early as 1834 the city was authorized to borrow $\$ 200,000$ for construction of water works ${ }^{114}$ or to contract for such service, ${ }^{115}$ plans for water works did not materlalize during this period. Toward the end of the period the council became engaged in greater enterprise. By legisletive acts the city was permitted in

${ }^{110}$ See City Journal, Vol.1, Oct. 12, 1830, pp. 392-3; Feb. 26, 1831, and passim.

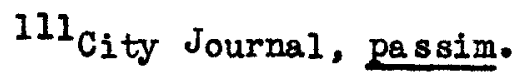

112 An Act to incorparate the Mechanics' Fire Engine and Hose Company of Louisville, February 24, 1834, in Collection of Acts, 1839 .

113 An Act to Incorporate the Louis ville Gas and Water Company, Feb. 15, 1838, in Elliott, op. cit., p. 103.

${ }^{114}$ An Act to amend the charter of the City of Louisville, Feb. 22, 1834; Ibid.

${ }^{115}$ Ibid. 
1838 to buy 4,000 shares in the Louisvilie Gas and Water Company, 116 and in 1848 an act was passed granting the city the right to raise a subscription of $\$ 500,000$ for the Frankfort and Louis ville Railrcad by a tax of one per cent in the real and personal estate of the city. Each person who paid the tax was entitled to his pro rata share of stock. 117 There was some criticism of this method of financing the building of railrads for, as the Louisville Democrat pointed out - - The result was that nino-tenths of the taxpayers, as a matter of nocessity in most cases, sold their tax recoipts at half price. 11 fow men got all the stock at an enormous discount . . 118

It was, moreover, such heavy investments as the se by municipalities which helped to create the tremendo us municipal indebtedness of later years.

\section{The Council and Legislature}

The story of municipal devel opment in this country during the nineteenth century is the story of legislative interference in matters of purely local concern, and the relationship between Loulsvillo and the Kentucky legislature was neithe $r$ better nor worse than the arerage.

${ }^{116}$ An Act to incorporate the Louisville Gas and Water Company, Feb. 15, 1838, 10c. cit.

117 An Act to amend the charter of the Frankfort and Louisvillo Railroad Co., Feb. 29, 1848, K. S., Ch. 450, Sec. 6.

118 Louis ville Democrat, March 16, 1851. 
Some of the limitations on the actions of the mayor and the council were, to be sure, enacted by the legislature as safeguards from the municipality, to protect the people of the city against mismanagement by those in public office. The concurrence of a majority of the council were required.

- . in electing any of ficer elective by the council; in the purchase and salo of real estate; in contracts involving the expenditure of money; in allacts for raising money; in all appropriations of money (except for the payment of fixed salaries and wages) and in the ssage and repeal of ordinances a. 119

The fiscel powers of the council were likewise limited. Payment of all contracts, other than those specified in the charter, within the fiscal year, was made mandatory ${ }^{120}$ and loans were limited to the anticipated revenue of the current fiscal year. The charter placed restrictions on both council and legislative action in providing that

- . If the legislature shall, hereafter, authorize the council to make contracts, or obtain lans contrary hereto, unless otherwise specifieally provided, it shall not be lawful for the council to make such contract, or obtain such loan without the previous assent of a public meeting of the citizens, to be convened for that purpose, after ten days' previous notice and publication of the law in two published newspapers printed in Louisville... 121

119 Amend., Jan. 16, 1838 , Sec. 6; also, Amend., Feb. 1, 1833, Sec. 5, loc. cit.

${ }^{120}$ The re were certain exceptions; completion of the courthouse; erection of workhouse and jai 1; contract wi th Louisville Medical Institute; improvement of square designated for university; and purchase of city wharf.

${ }^{121}$ An Act to amend the Charter of the City of Louisville, approved Jan. 16, 1838 , Sec. 6 . 
Certainly there is no outstanding instance during this period in which the State legislature attempted to impose its will against the best interests of the city inhabitants, although it did tie the hands of the council tightly wi th legislative red tape. The special legislation for the city might, at first glance, lead one to believe that very little discretionary power bel onged to the councilmen. To a great extent this was true. On the other hand, much of the legislation concerning Louisville so initiated by the council. The City Journal makes frequent mention of committees appointed to petition the State lawmakers. At on time a committee was ap pointed for the general purpose of determining "whether any, and if any, what amendments ought to be made to the city charter."122 Usually such council action was based on current needs and specific grants of authority were requested as, for example, the petition to the State legislature "for a portion of the funds and lands belonging to the Jeffersion Seminary and the fines and forfeitures accruing within this city for the use and benefit of the public schools of this city"l23 or the Council resolution

- . That our Representatives be requested to obtain a law at the next session of the Legislature, authorizing the city to purchase a site and right of way for the water works, within or without the city limits; to borrow the money necessary to their erection, etc. 124

$$
\begin{aligned}
& 122 \text { City Journal, Vol. 2, Oct. } 30,1829, \mathrm{p} \cdot 65 . \\
& 123 \text { Ibid., Vol. 14, 1847-1849, p. } 325 . \\
& { }^{124} \text { Ibid. }
\end{aligned}
$$


Initiation of legislation within the local community was common practice before 1850 throughout the country, and state legislatures deroted much time to special and $10 a l$ acts. 125

While the Kentacky legislature in no wise rivalled the Ohio legislature which passed 545 special and local acts during one session $(1849-50),{ }^{126}$ some 25 acts relative to Louisville were passed between 1828 and 1850. Many of these acts were local in scope and might well have been left to local action through more general grants of authority. It is indeed questionabb wether a state legislature should concern itself with such details of local government as are contained in one act passedin 1835

That it shall be lawful for the mayor and council of the City of Loustille, on the application of William H. Boothe, to discontinue the tobacco inspection at $h$ is warehouse in Louisville - - and the mayor and council shall have power and authority to establish another tobacco inspection and warehouse in the City of Louisvilio... 127

Such enactments by the gene ral assembly, eren when initiation of the law is local, are apt to result in a mass of pieco-meal legislation detemined by immediate expediency and political maneuvers rather than by long-range planning. The council was placed in the position of requesting more and more grants of authority as the city grew. Moreover, legislation for the largest tow in the state often met with hostility according to the writer of the following:

\footnotetext{
$125 \mathrm{Kneir}$, 오 cit., pp. 54-55.

${ }^{126} \mathrm{Fairlio}$ Municipal Administration, p. 85. 127 Act of Feb. 28, 1835, in Elliott, o․ it., p. 83 .
} 
The most superficial observer cannot but see that a spirit is rapidy developing itself in the Legislature of Kentacky which aims at depriving Louisville of that fair share of Legislative protection to which she is entitled.. The hostile spirit we allude to is exhibited in the progress of every debate that takes place in the councils of our state. No matter what may be the subject of deliberation, . . the damming of rivers, the formation of Railroads [etc.] - . each and all are eagerly seized upon by a strong and united party as the thome of a loud and angry declamation against the interests of the city ... I28

By 1850 the laws governing the city had been amended in some instances to the point of ambiguity and contradiction. The city clerk found it impossible to prepare lists of voters because amondments and elections were so "contradictory, indefinite, and obscure. 129

Pursuant to an amendment providing for a charter convention, 130 the council passed a resolution calling $f \alpha$ a vote on the subject at the next election. The resolution declared, in part:

Whereas, there have been many conflicting amendatory acts of the Legislature passed since the Charter of 1838 which renders a correct understanding of the charter at this time difficult and whereas some of said acts are in contradiction to the will of the majority of the voters of this ci ty as we believe

Therefore, Be it resolved . . that the question of remodeling the city charter or making a new charter.. be submitted to the voters of said city ... 131

The piling up of amendments had undoubtedly resulted in morass of vague and contradictory detail. But there was, possibly, another

${ }^{128}$ Louisville Journal, editorial, Jan. 17, 1836.

${ }^{129}$ City Journal, March 18, 1850, p. 146; Amend., Mar. 5, 1850, Acts of General Assembly, 1850, Ch. 399, Secs. 2-3.

130 Acts of General Assemb 1y, 1850, Ch. 399, Sec. 6 .

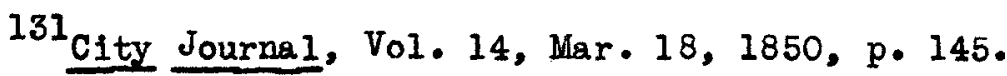


and more significant reason for revising the charter. After 1838 there had gradually emerged a changing viewpoint concerning the purpose and functions of municipal government. Increased urbanization was demanding expansion of municipal activities. The day had passed when it could be said that ". . the power of laying, collecting, and disbursing... taxes, together with that of opening, grading, and paring streots comprise the whole or very nearly the wole of the powers and duties of the mayor and council." 132 Louisville, like other cities in the Hississipgi Valley, was a focal point in the growing west. The ers of railrcadbuilding was at hand. Trade and comerce were the life-blood of a city located at the falls of the Ohio, and wisely or unwisely the city govornment sought to further those comerciel interests. Meanwhile a group rose to champion the small taxpayer and the citizen who paid no tax at all. This group, which sought not only the abolishment of the tax-paying qualification for voting but also such increased benefits as better schools, extension of streets and gas pipes, became the proponents of the new charter. 133

132 Louisville Daily Journal, Jan. 25, 1837, editorial . ${ }^{133}$ Louisville Democrat, 1851 , passim. 
CHAPTER III

LOUIS VILLE UNDER THE SECOND CHARTER

$1851-1870$

The 1851 charter was adopted just at the moment when the sweep of democracy in government was at its height and when democracy had become synonymous with popular election of gor ernment officials. Prior to 1850 municipal administration in most cities had been in the hands of the council, who determind policy, elected city officials, and controlled action through council committeos. After 1850 the power of the councll, generally, began to wane as the tendency toward subdividing administrative functions among boards and departments headed by popularly elocted chiefs came into rogue. At the same time there was a marked extension of municipal functions, which not only entailed an ever increasing amount of special legislation but also provided ample opportunity for the growing influence of the spoils system. 1

Louisville's second charter introduced major changes in structure and administration, and the circumstances attending its adoption reflect the temper of the times. Instead of an election of delegates to the charter convention by the voters qualified under the amended 1828 charter, the election was thrown open to "all free white male

${ }^{1}$ Fairlie, Municipal Administration, pp. $92 \mathrm{ff} \cdot$; "Historical Devolopment of Municipel Govemment in the United States,", in McLaughlin and Hart, Cyclopedia of American Govermment, p. 481. 
citizens of Louisville, entitled to vote for members of the Legislature of Kentacky." since the re was no tax-paying qualification in the Kentucky constitution, ${ }^{3}$ this provision extended suffrage to mary who had never before voted on municipal affairs.

In July, four delegates from each ward were elected to the charter convention, which met in September. The new charter was submitted to the voters of the city on January 11, 1851, and while it was approved by a majority of 250 , the decision was far from unanimous. 4 A newspaperman's report of a mass meetin held the night before the election presents an interesting account of the split in 1 ocal public opinion:

- - Generally speaking the aristocracy opposed, and the commonalty supported it the new charter, and, as usual in such contests, the latter triumphed. The rich were opposed to the increase of taxation, wich this charter would bring upon them. It proposed a new public school tax, laying out, lengthening and improving streets, extending the gas works, and various other matters. They were doing well enough -- were able to school their ow children, and why should they be taxed to school others? And for the city improvements, she was growing fast enough, and let all those who want the streets, etc., extended, go ahead and build, and improve, and then we will let them have streets, alleys, side-walks, and gas fixtures, for then they will be able and willing to pay for them. But the other party reasoned thus : Let all property be taxed for public school purposes, and thus establish schools to educate the richost, as well as the poorest, for if "knowledge is the true guide to liberty," all are personally interested in its

${ }^{2}$ City Journal, Vol. 14, May $29,1850$.

3 Kentacky Constitution, 1850 , Art. II, Sec. 8.

${ }^{4}$ Daily Courier, Jan. 13, 1851; Vote for the new charter, 1717; for the old charter, 1466 . 
spread. Also, extend the streets and sidewalks, and lay down the gas pipes, thus bringing cheaper lots into market, and offering inducements to every mechanic, and small 1 iver, to build houses for themselves, instead of paying the present exhorbitant rents. The increase of taxable property would so on reduce the taxes to the present rate, if not far below. This is the way to cause our city to thrive... 5

The charter, drawn up and approved by the citizens of Louisville, was enacted into law by the legislature on March 24, 1851. Chief among the innovations incorporated in it were the bicameral council, the mayor's veto, white manhood suffrage, and the long ballot. The pattern of the national government was adhered to in the provision that

The corporate powers of the city of Louis ville shall be divided into three distinct deparments, viz: Legislative, Executive, and Judicial; and no of ficer in one of these departments shall exercise any power belonging to either of the others, except as hereinafter permitted...6

Legislative power was vested in a board of common councilmen and a board of aldermen, which togethe $r$ comprised the general council of the city. One alderman and two common councilmen were elected from each ward. 7

\section{Elections and Voting}

The el ector who und er the old charter had voted far four candidates for office, in 1851 had sixteen choices to make. An alderman,

5 Account written for paper in Carrollton, Illinois, Jan. 20, 1851, repriated in Louisville Democrat, Feb. 13, 1851, p. 2, col. 3.

${ }^{6}$ Charter of 1851, Art. II, Sec. 1, Acts of the General Assembly, 1850 , Ch. 692 .

7 Ibid., Art. III, Sec. 1. 
Charter of 1851

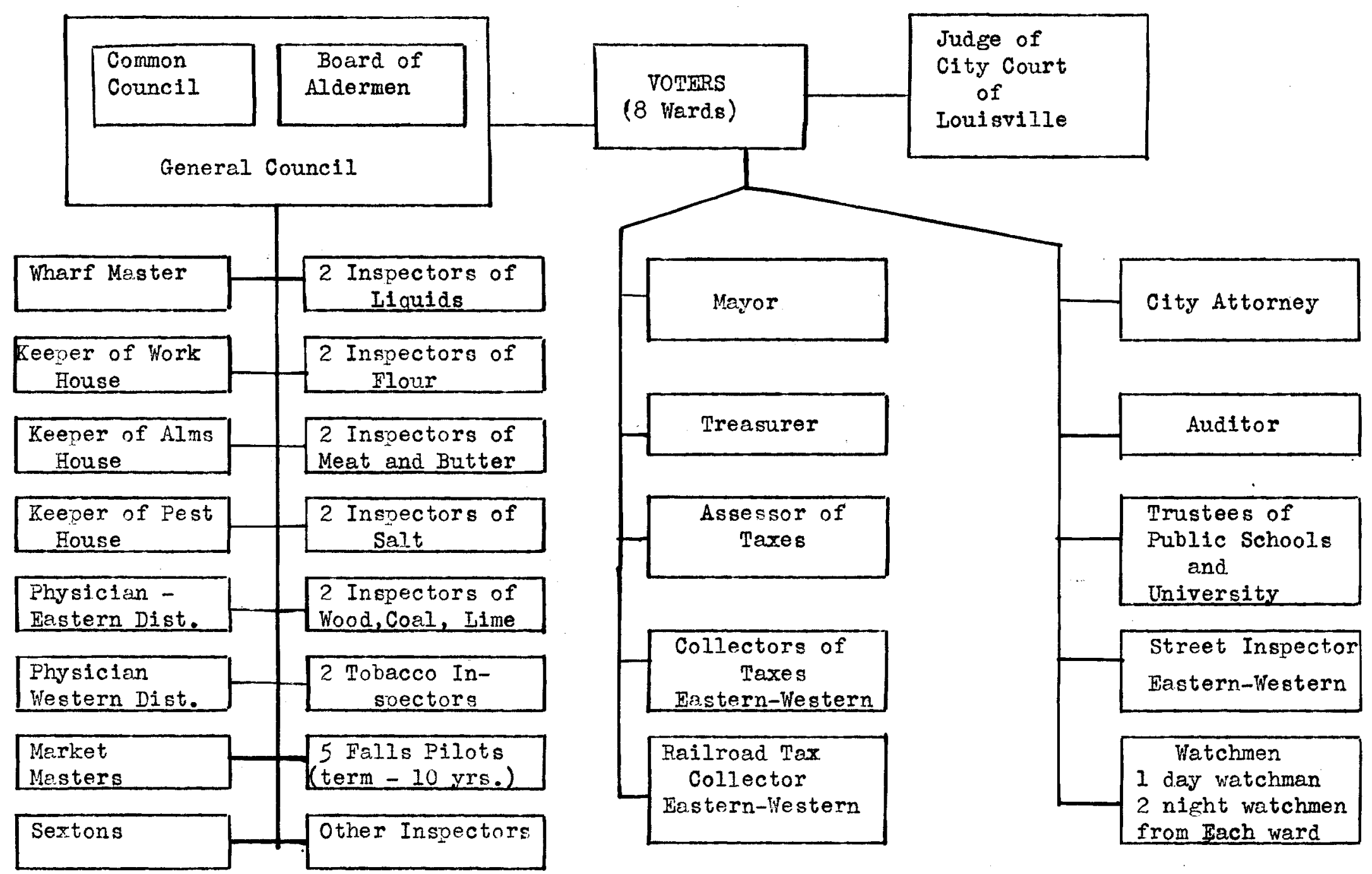


two common councilmen, a day tchman, two night watchmen, and two University and school trustees were elected from each ward. Election on a city-wide basis included the mayor, city attorney, assessor, auditor, and treasurer; in addition, the city was divided into eastern and western districts, each district voting for a tax collector and a street inspector. 8 Between the passage of the second charter and 1870 , several changes were made in elective offic es. Watchmen were elective from 1851 to 1856 and again between 1860 and $1861 .^{9}$ In 1868 , the office of chief engineer of the fire department became elective, and at the same time the of fice of city attorney was transferred to the county election slate. 10

The qualifications and tenure of of fice for mayor and members of the council will be discussed later. Of the other ele ctive officials it may be said that, on the whole, the terms of office were short and the qualifications for office, few. The status of qualified voter and bona fide resident of the city for one year, and a resident of the ward or district from wich elected, were general ly the only

${ }^{8}$ Charter of 1851, Art. IV, Secs. 8, 12. Provision for the election of last two of ficials was left up to the general council, and wile from 1851 on, a railroad tax collector was elected, the ballot never provided for a license inspector.

\footnotetext{
9 Acts of the General Assembly, 1856, Ch. 442, Secs. 1 and 2; 1860, Ch. $852, \frac{\text { Acts }}{\operatorname{secs}} \cdot \frac{\text { of }}{2-5}$.

10 Amend., Feb. 26, 1868, Acts of the Gene ral Assembly, 1868, Ch. 568, Sec. 1 ; Ch. 569, Sec. Acts of the Gene ral Assembly, 1868 ,
} 
requisites. The major exception was the city attorney who was required to have been for two years a licensed practicing attorney. The city attorney, auditor, treasurer, assessor, and trustees of the university and schools served for two years; other officers, for one year. Vacancies were filled by special election of the voters of the city, district, or ward in which the vacancy occurr ed. 11

The charter granted suffrage in municipal elections to all free, white, male citizens above the age of twenty-one and required only that the voter be a resident of the city for one year or of the state for two years and a resident of the ward in which he voted for sixty days. 12

No property or tax-paying qualifications for voters were contained in the charter, but an amendment requiring payment of a polltax in order to vote was submit ted to the city electorate in April 1857, approred by them $\mathrm{m}^{13}$ and enscted into law the following year. This act provided that " . - In elections for officers for the City of Louisville. - no person shall vote who has not first paid his poll tax. - twenty days before he offers to vote.." 14 A poll-tax of $\$ 1.50$ had been levied, by the Charter of 1851 , on each white male inhabitant of the age of twenty-ore or orer; but the payment of such tax

${ }^{11}$ Charter of 1851, Art. II, Sec. 8.

12Charter of 1851. Art. XI, Sec. 5 .

${ }^{13}$ Louisville Democrat, Apr. 5, 1857.

${ }^{14}$ Acts of the General Assembly, 1858, Ch. 828, Secs 1 and 2 
had not been made a prerequisite for voting. 15 The tax-paying qualification, however, was transitary, being repealed by the legislature two years later. 16

The eight wards into which the city had been divided in 1838 continued to exist for some years after the passage of the second act of incorporation. The Cha rter of 1851 provided that the city be laid off into wards "not exceeding twelve" and further prescribed that the general councll redistrict the wards of the city on the basis of enumerations of the city to be made in 1857 and every eight years thereafter. ${ }^{17}$ No record has been found wich indicates that this was dono. An act of the legislature in 1861 divided the city into ten wards, again granting the general council permission to change the boundaries as the need arose, and a similar act in 1868 provided for eleven wards. 18 In 1860, for the first time, the city said off into precincts; this was accomplished by commis sioners appointed by ne for the purpose by the state legislature. Thereafter, in all municipal, state, and federal elections a voter was entitled to vote only in his own precinct. 19

${ }^{15}$ Charter of 1851, Art. VI, Secs. 1 and 2.

16 Acts of the General Ass embly, 1860, Ch. 567.

${ }^{17}$ Charter of 1851 , Art. III, Sec. 3 .

18 Amend., Mar. 29, 1861; in Elliott, op. cit., p. 313; Amend. Mar. 2, 1863, Acts of the General Assembly, 1863, Ch. 944.

${ }^{19}$ Acts of the General Assembly, $1860, \mathrm{Ch} .880$. 
While state and county officers were still elected in August, 20 municipal elections continued to be held on the first Saturday in April. The conduct of elections in the hands of the general council who prescribed regulations and appointed election judges. The bi-partisan principle was observed in the charter provision that, "if practicable," election officers should be chosen in equal numbers from the two principal parties. 22 The moth of voting was changed from viva voce to ballot by charter provision. 23 The council prescribed the order, 24 but provided for no official printing of ballots. It did require, however, that ballots be so folded that names should not be exposed and that they be written in ink or printed. 25 Warning s to voters appeored in the newspapers not to throw away their votes by writing with lead pencil! 26 Varlous ruses were apparently employed to nullify the secrecy of the ballot. Candidates were even accused of having their ballots printed on paper of

${ }^{20}$ Kentucky Constitution, Art. III, Sec. 26.

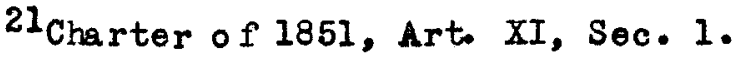

22 Charter of 1851 , Art. XI, Sec. 3. According to the Louisvillo Courier, April 5, 1858, judges were appointed from ranks of party without regard to this article.

${ }^{23}$ Charter of 1851 , Art. XI, Sec. 4.

${ }^{24}$ Revised Ordinances, 1854, No. 24.

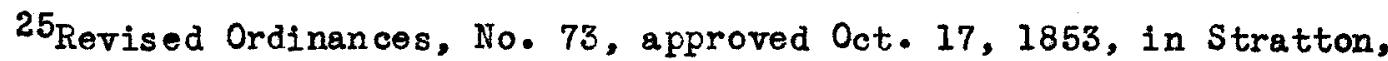
0 . H. and Vaughan, J. M., A Collecti on of State and Municipal Laws, Louisville, Ky•, Settle, 1857, p. 180 .

26. Louisvilie Democrat, Apr. 1, 1854. 
unusual color that they might be more easily recognized by party workers. 27 The ballot hardly seemed the answer to the problem of corruption at the polls, and in 1860 the section of the charter providing for election by bal lot was repealed and elections viva roce reestablished. 28

Throughout the period special elections were held frequently. Proposed amendments, ordinances involving municipal indebtedness, and vacancies in certain offices were submitted to the voters; also, in the erent of a tied vote between two candidates, a now election was held. 29 Such elections were held in accordance with regulations prescribed by the council, but an act of the general assembly passed in 1856 made it mandatory that notice of the special election authorized by that act should be publishedin two or mare of the city's newspapers three days prior to the election. 30

Contested elections were heard and decided by the general counci1. 31 An ordinance passed April 10, 1852, and continued in force until the adoption of a third charter in 1870, provided that, when the elec-

27 Louis ville Democrat, Apr. 1, 1859.

28 Acts of the General Assembly, 1860, Ch. 852, Sec. 1. Dumb persons continued to be entitled to vote by ball ot.

${ }^{29}$ Charter of 1851, Art. IV, Sec. 16.

30 Acts of the General Assembly, 1856, Vol. 1, Ch. 124 .

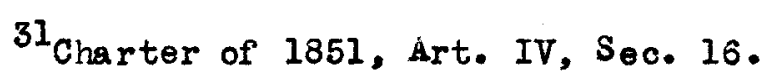


tion of any officer other than a member of the general council was contested, the presidents of both boa rds should constitute a committee to determine the contest subje ct to the approval of the $\infty$ uncil; and that each board should determin contested elections of its own members. It also prohibited citizens from contesting elections, except on grounds of ineligibility; on all other grounds only the defeated candidate was allowed to contest. 32

The most outstanding characteristic of elections during the years under the second charter was the cor rupti on which accompanied them. While the population of Louisville increased by a third during the decade between 1850 and 1860, the total vote cast in municipal -lections (see graph on p. 72) dropped rapidly after 1855, reaching its nadir in 1857 and thereafter mounting gradual ly until the Civil War period. Even on the assumption that the population increase represented wholly an influx of for eigners, one would be forced to the unlikely conclusion that the re was a simultanoous oxodus of citizens. A study of newspaper accounts and commentary is, however, quite reroaling. In 1855, the Americen or Know-Nothing Party, which the previous year had succeeded in carying a few candidates into office, swept into power. The Daily Courier, while heralding the victorious party with praise, said of the election that

- - considering the many el ements brought to bear on the

${ }^{32}$ Ordinance No. 55, Elliott, op. cit., pp. 553-55. 


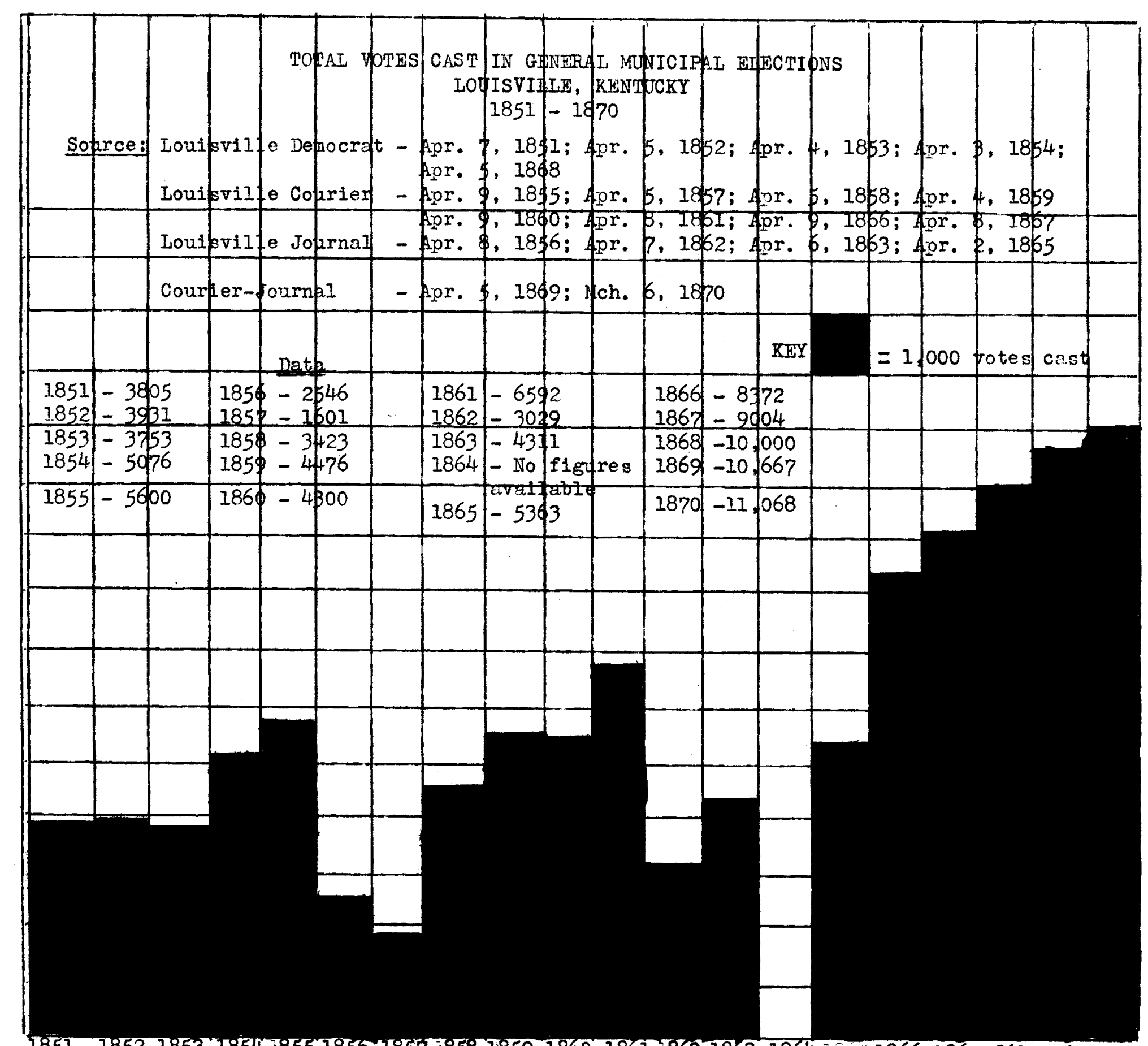


many conflicting interests, and the deep feeling manifested, and the unusually heavy rote polled, [it] was remarkably quiet and orderly.. 33

Unfortunately is sues of the Louisville Democrat, a forceful foe of Know-Nothingness, are lacking for this date. The victors already had the support of the partisan Daily Journal, according to whose view "the election - . passed off with comparative quietness" with only "a few fights in the Second and Eighth wards."34

The number of votes cast in the 1856 municipal election decreased sharply, a decrease in all probability reflecting the mob rule of terror on "Bloody Monday," the August 6, 1855 state election date, when the quarrel between foreign-born and native Americans had culminated in bloody conflict. The election was again a Know-Nothing victory; but the Courier, which had earlier la uded the American party's rise to power, now expressed the opinion that ". . there appeared to be a general feeling provalent to acquiesce in the present maladministration of city affairs. " 35

The lowest point was reached in 1857, wen only 1601 voters cast their ballots in what, according to the Louis ville Democrat, was "by courtesy styled an election," for the Know-Nothing Party maintained their hold on the city without any o ther contenders for most of fices. 36

${ }^{33}$ Louisville Daily Courier, Apr. 9, 1855.

${ }^{34}$ Louisville Daily Journal, Apr. 9, 1855.

35 Louisville Courier, Apr. 7, 1856.

${ }^{36}$ Louisville Democrat, Apr. 5, 1857. 
The following year a citizens' ticket was offered in opposition; but while the vote increased it was estimated that less than half of the voters went to the polls; and a Know-Nothing victory was again conceded. The Courier deplored "the process of disenfrenchising citizens by allowing head breaking, terror, an fraud, 37 and the Democrat agreed that "the election was attended with customary outrages and insults - . rascality, ruffianism, and illegal voting."38

In 1859 there were reports of the "bruising and beating of naturalized citizens by a pack of lawless scoundrels" and according to the press, in one ward two Jewish persons were attacked and fired upon. "The policemen," the Courier noted, "made themselves conspicious as usual by druming up roters instead of attending to the ir legitimate duty and preserving public order." 39 During the same period similar violence was reported in other cities, notably $B_{a}$ ltimore and New Orleans. New Orleans was under mob rule during the election of 1857 and three thousand rogistered voters were reported to have been driven from the pol1s. 40

The Know-Nothings were defeated in 1861 after seven years' rule

${ }^{37}$ Louisville Courier, Apr. 5, 1858.

38 Louisvillo Democrat, Apr. 4, 1858. Of the "Citizens' ticket" only 2 aldermen and $\frac{1 \text { mmon }}{1}$ councilman were elected.

${ }^{39}$ Louis vi Lle Democrat, Apr. 3, 1859; Louisville Daily Courier, Apr. $4,1859$.

40 Louisville Democrat, Apr. 2, 1857. 
and at the same time rioting at the polls subsided, al though reports of "lavish distribution of mony," illegal voting and free use of "all -lectioneering appliances" continued throughout the period.

During the war years, the number of rotes cast in elections diminished, as might reasonably be expected when a large segment of the voting population was under arms. Interestingly enough, despite the position of Kentucky in the Union, two pro-sedessionist mayors were elected. In both instances, according to the Louisville Daily Journal, the choices were made on the basis of local rathor than national interest. On the subject of Mayor Kayo's election in 1863, the Journal offered the o pinion that

- - The success of Mr. Kaye over the regular Union candidate is on many accounts deeply to be regretted, but it possesses no significance whatever as an index of the public sentiment of Louisville. The result was brought about simply by a conflict of local interests and feelings, in which the secession element of the city, ever on the alert to win at least a show of advantage for the rebellion, mingled as the deciding power... 41

In the el ection of Mayor Tomppert in 1865, according to a Journal. editorial:

- Less interest was ovidently felt in the election than the occasion demanded. It seems that a community, watching in the distance the ovolution and $\infty$ llisions of great armies a marking the grand procession of mighty events, cannot afford to give themselves much concern about the election of officers to control their municipal affairs.

We cannot imagine for a moment that the citizens.. . In electing $\mathrm{Mr}$. Tomppert, had the least thought of indorsing his opposition to the furnishing of men and money to carry on the war... We can

${ }^{41}$ Louis ville Daily Journal, Apr. 6, 1863. 
not understand why they ignared so important a matter, but they clearly did... 42

In summary, it may be said that, a 1though the suffrage base had been decidedly bradened by the 1851 charter, suffrage, prior to the Civil War was not truly representative. Between 1855 and 1860 it was actually restricted through violence at the polls. During the Civil War the voting "depression" can be accounted for partially by the absence of men for military duty and partially by the fact that national affairs eclipsed local is sues. After the war violence was absent from elections, but it may be presumed from contemporary conment that bribery and corruption continued unabated. During the entire period national political parties played a far more important role in municipal el ections than hed been the case in earlier years.

\section{The Mayor and Council}

The qualifications for mayor and councilmen provided by the 1838 amendments to the old charter were retained in the 1850 charter with some few differences. The age of eligibility for the office of mayor was raised from twenty-five to thirty years; the minimum ages established for council members, which previously had been twenty-five years, were twenty-four for common councilmen and thirty years for aldermen. Citizenship and, until 1865, residence qualifications were virtually

${ }^{42}$ Louisville Daily Journal, Apr. 2, 1865. 
the same as before; after 1865 the length of residence required of any elective officer was reduced to one year in the city and two years in Jefferson County. 43 The really fundamental change, however, was the abolishment of all tax and property-hold ing requirements, a change in line with the general trend of popular government in mast other municipal charters of the period. ${ }^{44}$ Another modification of somewhat lesser importance, reflected the expanding function of municipal government in the area of public works. Although both members of the general council and the mayor were prohibited from having any direct or indirect interest in contracts, a new provision made stockholders eligible for office on the condition that they not rote on questions affecting that interest. ${ }^{45}$ Unfortunately experience has proved that mere legislation against colIusion does not assure honest and pure government.

The mayor was elected for a two-year term as were aldermen; common councilmen served for one year until 1865 when the term of office was extended to two years. ${ }^{46}$ Because of the vague wording of the charter, the meaning of "term of office" as applied to the mayoralty became a source of confusion almost immediately. Mr. Delph, the first mayor,

${ }^{43}$ Charter of 1851, Art. IV, Sec. 1; Art. III, loc. cit.; Amend., Mar. 4, 1865, Sec. 16; in Elliott, op. cit., p. 141 .

${ }^{44}$ Fairlie, Municipal Administration, p. 84; Munro, Government of American Cities, p. l1.

${ }^{45}$ Charter of 1851 , Art. III, Sec. 2 , 10c. cit.

${ }^{46}$ Charter of 1851 , Art. IV, Soc. 2; Art. III, Soc. 4, 1oc. cit.; Amond., Juno 2, 1865, Elliott, op. cit., p. 141 . 
resigned his office after an incumbency of only a few months, but was subsequently elected by the general council to serve as mayor pro tem until April, 1852. 47 At that election the voters placed James Speed in the executive office. Whereupon, the questi on arose whether his office terminated in 1853 or in 1854 -- that is, whether a mayor was elected for a two-year term, $\alpha$ whother that term was fixed in certain definite years. For thre years, it remained a moot point; legal opinion was divided and the two bards of the council could reach no agreement. Nevertheless, a sufficient number of voters continued yearly to write Speed's name on the ballot to enable him to retain office until 1855; during that period, however, he sas never awarded an election certificate, so shifting was the sentiment of the council. 48

In 1855, however, despite the declaration of $M r$. Speed, supported by the opinion of the Chancellor of the Louisville Chancery Court, that: no vacancy in the mayoralty existed, 49 the polls were opened for mayoral election by joint resolution of the general council, 50 in their first agreement on the matter. John Barbee received tine majority vote of the - lectorate, and was recognized as mayor by the council in a resolution

47 Journal of the Board of Ald ermen, Vol. 1, Oct. 9, 1851.

48 Louisville Democrat, 1851-1854, passim; Louisville Journal, April 3, 1855; Journal of the Board of Ald ermen, Apri1 6, 1853, Mar. 13 and 22, 1854, and passim 1851-1855.

49 Journal of the Board of Aldermen, Vol. 4, Feb. 1, 1855, pp. 43-5.
$50_{\text {Ibid., Feb. } 23,1855 .}$ 
passed over the former mayor's veto. 51 Council action was upheld by opinion of the Court of Appeals which declared that a term is uniformly used to designate a fixed and definite period of time. 52

An innovation in the charter of 1851 was the provision for payment of members of the generalcouncil at the rate of $\$ 2.00$ a day for each day in attendance, but this compensation was eliminated by rote of the citizens in April, 1857, ${ }^{53}$ followed by statutory repeal. 54 The mayor's salary remained fixed at "\$2,000 per annum payable quarterly and no more" until 1864 when it wa increased to $\$ 2,500$. The following year a more flexible policy provided a minimum and maximum salary of $\$ 2,000$ and $\$ 4,000$ respectively. 55

The charter provided that vacancies occurring on either board of the council should be filled by a special election of the qualified voters of the ward in wich the vacancy occurred, unless it occurred

\section{${ }^{51}$ Ibid., Apr. 10, 1855, p. 152; Apr. 13, 1855, p. 157. \\ 52 Barbee vs. Speed, MS Opinion, June term, 1855, cited in 3 ilet} (Ky. 60) 213 and 2 Dur (Ky. 63) 468 Lriginal opinion not available due to the fact that unpublished opinions were destroyed when clerk's office in Court of Appeals burned, November 1865.

${ }^{53}$ Louisville Democrat, Apr. 5, 1857.

${ }^{54}$ Amend., Feb. 17, 1858, Acts of the General Assembly, 1858, Ch. 828, Sec. 2 .

${ }^{55}$ Charter of 1851, Art. IV, Sec. I; Amend., Feb. 18, 1864, Acts of General Assembly, Ch. 417, Sec. 3; Amend., Feb. 16, 1865, Sec. 1 , EIliott, op. cit., p. 135. 
within three months of the general municipal election; in that case the mode of choosing a successor was 1 eft up to the general council. The council decreed that vacancies of the latter category should be filled by election by joint session off the council. After 1864 the provisions of this ordinance were enacted into $19 \mathrm{w} .{ }^{56}$ Vacancy in the office of mayor has already been discussed in the section on roting and elections, but it may be added that, in the event of a temporary vacancy, it was prescribed by charter that a mayor pro tem be elected on joint ballot of the general council and that he sorve during the continuance of the mayor's absence or until a mayor was elected. 57 An amendment de it permissible for the president of the Board of Aldermen to serve in that capacity. ${ }^{58}$ The general council was empowered to $f i x$ the salary of the mayor pro tem and a yearly salary of $\$ 2,000$ was established by ordinance. 59

The council was required to meet regularly once in every two weeks and neither board was pe rmitted to adjourn when both where in session for more than twenty-four hours without the consent of the

56 Charter of 1851, Art. III, Sec. 10; Revised Ordinances, 1854, No. 9, p. 72; Amend., Feb. 18, 1864, Sec. 4, Acts of the General Assembly, 1864, Ch. 417, Sec. 4 .

${ }^{57}$ Charter of 1851 , Art. IV, Sec. 7 . 1012, Sec. 58 Amend., Mar. 9, 1868, Acts of the General Assembly, 1868, Ch. No. 20.

${ }^{59}$ Charter of 1851, Art. IV, Sec. 7; Revised Ordinances, 1854, 
other. 60 A majority of members constituted a quorum of either board although a smaller number was permitted to adjourn from day to day and to compel the attendance of absent members by fines. Each board determined its own rules of procedure, elected its own president and clerk annually, and judged the qualifications, elections, and conduct of its members. 61

The procedure for the passage of an ordinance was essentially the same as that of a state or foderal law. A proposed ordinance was read and freely discussed on two separate days by each board, unless, in cases of urgency, a two-thirds majority of the board agreed to suspend the provision. 62 After being passed by both boards, the bill was presented to the mor for approval and became effective if signed by the mayor or if pessed over his veto by a simple majority of both boards. Should the mayor fail to sign, the proposed ordinance took effect after one week unless in the meantime the council adjourned; in that event it became an ordinance unless the mayor returned it to the council at its next meeting. Whenever the mayor disapproved a proposed ordinance, he was required to submit his objections in writing; these objections were then entered into the journal of the board. Revenue bills originated solely in the Board of Common Councilmen, but

$$
\begin{aligned}
& { }^{60} \text { Charter of 1851, Art. III, Sec. } 8 . \\
& 61_{\text {Ibid., Art. III, Secs. } 5-6 .} \\
& 62_{\text {Ibid., Art. III, Sec. } 11 .}
\end{aligned}
$$


could be amended by the Board of Ald ermen provided that no irrelevant matter was introduced. 63

Ordinances and proceeding of both boards were required by charter to be published" - . at least once, in one or more daily newspapers printed in Louisville -- such newspeper or newspapers to be selected annually by the general council." 64 From newspaper comment one might judge that this method was open to abuse. In any event, the provision was revised in the 1870 charter to require publication in the Louisville daily paper "having the largest permanent circulation in the city." 65

The office of may carried with it little more power under the 1851 charter than it had under the original act of incorporation. Other than the right of veto, wich was accorded the mayor of Louisville some twenty years after similar authority had been granted the mayor of New York, ${ }^{66}$ the mayor had little control in the administration of the city government. According to cherter provision, the mayor was hoad of police. This, in fact, was littlo more than an empty title when one considers that the regular force of night and

${ }^{63}$ Charter of 1851, Art. III, Sec. 12; Art. IV, Sec. 5. 64Ibid., Art. III, Sec. 7.

65 Charter of 1870 , Sec. 5 , in Charter of the City of Louisville and Ordinances, June 24, 1869 to Jan. 1, 1873, pp. 7-8. p. 51 .

${ }^{66}$ A. F. MacDonald, American City Government and Administration, 
day watchmen were elected by the voters of each ward, that supernumeraries were appointed by the marshal with the mayor's consent, and that police were removable only by the Board of Aldermen sitting as a court of impeachment. 67 Nor was this position as head of police enhanced through the passage of subsequent amendments.

In March, 1856, the election of watchmen by the voters was abolished and the general council emporered to establish a police department and to appoint the tchmen, or prescribe the mode of their appointment. 68 Mayor Barbee at that time urged that since the mayor was held responsible for the efficiency and faithfulness of the police that he alone should have the power of appointment and dismissal subject to approval of the general assembly. ${ }^{69}$ This was disregarded by the general council, who for the next four years elected annually a chief of police, who, in turn, with the council's approval, chose two assistants. The thirty-three regular and sixteen supernumerary watchmen were elected on joint ballot of the council. The mayor was given power to dismiss any watchman for misconduct or ineficiency. 70 Sec. 15.

${ }^{67}$ Charter of 1851, Art. IV, Sec. 8; Art. XI, Sec. 8; Art. IV, ${ }^{68}$ Amend., Mar. 8, 1856, Acts of the General Assemb ly, 1856, Ch. $442, \overline{\operatorname{Secs}} \cdot 1-2$.

${ }^{69}$ Proceedings of Board of Aldermen, Apr. 7, 1856, Louisville Dai ly Journal, Apr. 10, 1856.

700rd. No. 218, Apr. 7, 1856; Ord. 219, Mar. 10, 1856; Ord. No. 220, Apr. 24, 1856 in Collection of State and Municipal Laws, prepared by 0 . H. Stratton and J.M. Vaughan, Louisvillo, 1857, pp. 284-86. The se ordinances were passed over mayor's veto, see ref. in 69 . 
The police department underwent an other mojor revision in March, 1860. Police administration was transferred to a police board composed of the mayor, ex officio, and two qualified voters, the latter being chosen by the chancellor of the city court who had the power to appoint and dismiss them at will. The mayor "with the advice and consent" of the other members of the board appoint ed a chief of police and as many supernumerary tchmen as the mayor deemed necessary. Watchmen were once again chosen by the roters of the city, one day watchman and one night watchman from each ward. 71 It is hardly surprising, in this age of political patronage, that the only qualification required for the positions of police chief and watchmen was that of being a qualified voter. Members of the police board had to meet a further requirement of belonging to the opposite political party from that of the mayor, a qualification which the courts subsequently found to be unconstitutional on the grounds that the term for which the of ficers were to be elected was not fixed in that "they must be removed whenever by a change of politioal opinion on their part or the part of the mayor they cease to agree." 72

${ }^{71}$ Act to provide a more efficient Police Department in the City of Louisville, March 1, 1860, Acts of the Gene ral Assembly, 1860, Ch. 852, Secs. 2-5.

72 Speed and Worthington vs. Crawford, 3 Met (Ky. 60) 209, 213 ; the act was likewise decla red unconstitutional on the ground that it provided for "the appointment by the chancel lor or governor, of the two members of the police board, instead of requiring them to be elected." 
The foregoing organization was short-lived, being superseded the following year by a police department established by the general council. An amendmont passed in September, 1861, repealed the act of the previous year and returned to the council its former power of appointing watchmen and prescribing the irmode of election, term, tenure, duties, etc. ${ }^{73}$ A contemporary account of an election of watchmen may be of interests

- - the council chamber was crowded and an unusual stir was going on. The cause for the excitement was the election for the ensuing year. The members of the council, as they entered the building, were besieged on all sides by different parties who wore urging their claims for the office of police... The contention between the rival candidates was quite lively and the process of electioneering was kept up until the Board sas called to order, and the crowd were ordered outside of the railing . . . 74

Meanwhile the mayor had been deprived of his right to remove policemen from office, a power transferred to the general council by a charter amendment passed October 1, 1861. 75 From this time until the adoption of a new charter in 1870, the mayor's control of the police was inconsequential.

Other powers and duties of the mayor may be noted briefly. Ho exercised general supervis ory control over the executive officers of cities and had power to fill any vacancies in their ranks. The mayor

\footnotetext{
1 and ${ }^{73}$ Amend., Sept. 20, 1861, Acts of the Assembly, 1861, Ch. 44, Secs. 1 and 3 .

${ }^{74}$ Louisville Democrat, Mar. $28,1865$.

$75_{\text {Acts }}$ of the Assembly, 1861, Ch. 142, Secs . 1-2.
} 
provided the council with needed infermation, made such recommendations as he deemed necessary, and could convene the council for reasons of urgency. 76 In addition, he served as one of the commissioners of the Sinking Fund and as a health officer of the city. 77 In effect, the position of mayor continued to be one of prestige rather than authority. Chief among the powers of the general council were their powers of appointment and of negotiating municipal contracts. Jobs and contracts were powerful adjuncts to the spurt of municipal construction in these years and both powers opened the gates wide to all the orils of the spoils system. The Louisville charter permitted the council to elect annually, among others, the following: a wharf-master; keopers of the workhouse, almshouse, and pest house; two physicians, a number (prescribed by ordinance) of market masters; sextons; numerous inspectors, assistant tax-assessors, and falls pilots. ${ }^{78}$ In addition, the general council provided for the election or appointment of nurses, guards, and attendants at the eleemosynary institutions of the city, for workmen at the city quarry, and for servants for various officials.79 The hospital superintendent and even the graduate residents serving at the hospital were elected by the council. 80 The concensus seemed to

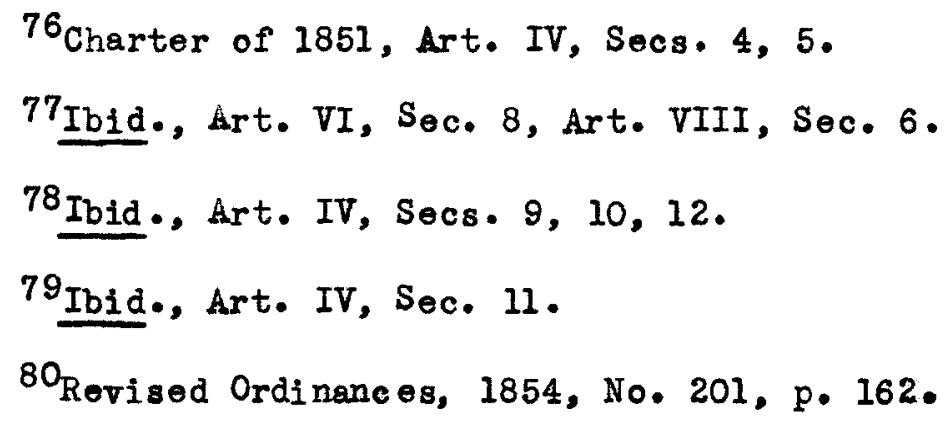


concur with the alderman who contended that the councll were as capable of selecting the graduates as were the consulting and visiting physicians of the hospital who were elected by the council! 81

Between 1851 and 1870 there was a continual creation of new offices by amendment and ordinance. The office of assistant city attorney at a yearly salary of $\$ 400$, elective bi-annually by the council, was created by ordinance in $1853 .^{82}$ In 1855, an Ingineer's Department was created, composed of an engineer and his assistant. 83 An inspector of imported lumber and an inspector of flour ware added to the city payroll in $1858 ;^{84}$ and in 1865 , a receiver of city taxes. 85 When manicipal offices with salaries were not instituted, boards for spending city funds were established. A board of five guardians for the alms house, for example, was elected annually by the council. The ordinance creating the board also prescribed that in making appropriations the board should "be governed by the amount set apart by the General Council for that purpose from time to time, and shall not exceed such amount." 86

${ }^{81}$ Council Proceedings, June 10, 1850, Louisville Daily Journal, June 11, 1850 .

82 Proceedings of the Council, March 21, 1853, Iouisville Democrat, March 22, 1853 . p. 187 .

830rdinance, approved May 19, 1855, Collection of Acts, 1857,

84 An Act to create the Office of Inspector of Imported Inmber in the City of Louisville, Jan. 14, 1858, Secs. 1-2; An act relating to the Inspection of Flour in Louisville, Feb. 15, 1858, Sec. I. Elllott, op.cit., 1869, pp. 8, 198, 301.

85 Amend., Mar. 4, 1865, Sec. 3. Mlliott, op. cit., p. 135.

86 Revised Ordinances, 1854, Ho. 202, Secs. 1, 7, 8; p. 162. 
The power of removal of city of ficials belonged, for the most part, to the Board of Aldermen, who sat as a court of impeachment in accordance with a charter provision that

Executive and ministerial officers of said city shall be removable from office by the board of aldermen sitting as a court, duly sworn or affirmed, upon charges peferred by the mayor . . . (but in case of the mayor, upon charges peferred by the board of common councilmen) and no porson shall be removed from office without the concurrence of two-thirds of the menbers of the board of aldermen. When a person has been removed from office, he shall not be re-eligible thereto until the expiration of the term for which he had been elected. 87

The most frequent cases triod involved charges against watchmen. The record of on session chosen at random is possibly typical; whatever evidence was presented at the trials was not recorded, but in the journals of the board the charges and judgments were as follows:

\begin{tabular}{|c|c|c|}
\hline Case No. & Charges & Judgment \\
\hline 1 & $\begin{array}{l}\text { Passing counterfiet bill } \\
\text { becoming embroiled in fight } \\
\text { striking and wounding citi- } \\
\text { zen. }\end{array}$ & Case $d$ ismissed \\
\hline 2 & $\begin{array}{l}\text { drunkenness } \\
\text { gambling }\end{array}$ & Case postponed \\
\hline 3 & $\begin{array}{l}\text { failure to discharge duty } \\
\text { frequenting coffee houses to } \\
\text { neglect of business } \\
\text { divulging confidential in- } \\
\text { formation }\end{array}$ & Charges di smis sed \\
\hline 4 & $\begin{array}{l}\text { boing in possession of } \\
\text { stolen watch } \\
\text { ongaging in dog fight } \\
\text { neglect of duty }\end{array}$ & $\begin{array}{l}\text { Charges dis missed } \\
\text { (wratchman re- } \\
\text { signed) }\end{array}$ \\
\hline
\end{tabular}

${ }^{87}$ Charter of 1851, Art. IV, Sec. 15.

${ }^{88}$ Proceedings of Board of Aldermen, Vol. 1, August 3, 1851. 
The most notable impeachment case, however, occurred some two years before the President of the United States was impeached. In Decernber, 1865, Mayor Tomppert was charged wi th "disregarding, failing, and refusing to carry into effect the lawful orders and requests of the general council of the city." According to testimony produced in court and the records of the boards, the general council passed a resolution authorizing the mayor to sign and execute a contract with one Isham Henderson and associates for a street railway. The resolution was retoed by the mayor, but was subsequently sustained by council vote of thirteen ayes to ten nays. The mayor, still refusing to sign the contract, sent the council a mossage stating that not only was the contract not binding on Henderson's associates but that improper influences had been used on members of the board in drawing up the contract; the mayor presented affidavits supporting his charge and suggested an investigation. Upon receipt of the message, the council preferred charges against Mayor Toinppert and a few days afterwards the Board of Aldermen sitting as a court of impeachment faund him guilty of the charges. 89 Upon the removal of the mayor, James Lithgow was elected to the office by the general council. The action of the Board of Aldormen was upheld by the Jefferson Court of Common Pleas but the decision was reversed in January, 1867, by the Court of Appeals which declareds The board of aldermen of the city of Louis ville, acting as a court to try charges preferred against a city officer, is a court

${ }^{89}$ Journal of the Board of Ald ermen, Vol. 10, Dec. 18, 1865, p.276. 
of limited jurisdiction, and everything essential to make it such a court must appear affirmatively . . The board of Aldermen of the city of Louis ville, as organized, not being legally sworn, 90 was not a legal court authorized to try Mayor Tompert [sic]; and the message, charges, and specifications preferred, made out no charge of official delinguency, and their proceedings, by wich he was ousted, were illegal and void. There was, therefore, no vacancy in the office of mayor for the general council to fill, and lithgow, the appointer of the council, became a usurper in legal contemplation.91

On February 14, 1867, fourteen months after he had been ejected from office, Tomppert was reinstated in the mayoralty and was instrumental in obtaining the passage of an act to legalize the official acts of James S. Lithgow as mayor of the city of Louisville.92

An interesting sidelight on the impeachment of Mayor Tomppert was the case of Common Councilman, N. S. Glove, against whom the mayor had preferred charges of bribery in connection with the Harrison Railway contract. Five days after the mayor had been removed from office, a resolution sustaining the bribery charges against Glove was defeated in the Common Council Chamber, whereupon, those voting in the affirmative presented their resignations from the board. The resignations were tabled and a new resolution expelling Glove for "unbecoming conduct" was introduced and passed.93 This was probably an action designed to save face; the common council had the power to judge the

90 Neither the clerk of the Board of Aldermen, the court pointed out, nor the notary public who administered the oaths was so empowered.

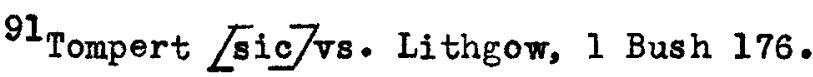

92 Laws of Kentucky. 1867, Vol. 2, Ch. 1699, Secs. 1-3, pp. 269-70. $77 \mathrm{ff}$.

93 Journal of the Common Councilmen, Vol. 10, Dec. 23, 1865, pp. 
conduct of its members, but sustaining the bribery charge would have necessitated trial by the Board of Aldermen.

These cases, along with other similar ones, would seem to indicate a high degree of irresponsibility in this phase of municipal government; but a lack of sufficient evidence in the records precludes any valid generalization.

Other powers granted the council und er the earlier charter were retained or broadened in the charter of 1851; and in addition new powers were granted. Chief among its broadened powers wat that of levying taxes. The 1828 charter had provided for an ad valorem tax not exceeding forty cents per hundred dollars assessed valuation of property. The 1851 charter authorized a similar tax of one dollar for general. purposes, including five cents for the support of the poor and a minimum of twelve and one-half cents and a maximum of twenty-five cents for schools, and an additional ad valorem property tax of seventy-five cents for special purposes of capital investment. 94 The poll tax levy authorized by the earlier charter was retained in the 1851 charter and license fees not only underwent upward revision but the businesses required to pay such fees were extended to include practically all merchants, wholesalers and retailers. 95 In addition the power to le vy a tax for gas lights was conferred by

\footnotetext{
${ }^{94}$ Charter of 1851, Art. VI, Secs. 2, 12, 100. cit.

95 Charter of 1828, Sec. 11, loc. cit.; Amend., 1838, Sec. 14;
} Charter of 1851, Art. IV, Sec. 14, Ioc. cit. 
charter and in 1860 an amendment empowered the council to impose on property owners an ad valorem tax of twenty-five cents for sower construction. 96

In addition to its increased power of taxation, other fiscal powers of the council were enlarged. A sinking fund was created by charter and the general council ses authorized

To subscribe for, hold and sell any real or personal estate within limits of said city, and to borrow money and to give or loan the credit of said city in aid of any person or corporation, but only for appropriate municipal objects. 97

The borrowing power was limited by reason of the required approtal of the voters for debts contracted beyond revenue of the current fiscal year $^{98}$ and the mayor and the council members were held personal ly liable for debt contracted contrary to statute. 99 From time to time the general assembly empowered the council to contract for municipal improvments and the city's.capital investments became increasingly larger. In 1862, for instance, the council s authorized to borrow as much as $\$ 75,000$ for the two fiscal years ending March 10,1862 and 1863 in addition to amounts previously expended or contracted for 100

${ }^{96}$ Charter of 1851, Art. VI, Sec. 14, 10c. cit.; Amend., Har. 2, 1860, Acts of the General Assembly, 1860, Ch. 1159, Secs. 1, 2, 4.

${ }^{97}$ Charter of 1851, Art. VI, Secs. 10, 11 .

${ }^{98}$ Ibid., Art. VI, Sec. 11.

99 Ibid., Art. VI, Sec. 10.

100 Amend., Feb. 19, 1862, Aots of the General Assembly, 1862, Ch. 383, Sec. 1 . 
By 1856 municipal indebtedness had reached $\$ 2,582,000,^{101}$ and by January 1,1871 it rose to $\$ 4,910,500.102$

Other powers conferred on the council reflected the growing urbanization of Louis ville. The council was empowered not only to prohibit the erection of wooden buildings but also

- . to prohibit the erection of manufacturing establishments deemed likely to crete the denger of fire or producing unpleasant effluvia; and to regulate the constmaction and mangement of such establishments within the thickly populated portions of the city ... 103

Administration of municipal functions sased out of the hands of the cuncll to a large extent during the period between 1851 and 1870. In some instances this control went to popula rly elected officials and in other cases to officials or boards chosen by the council. Administration of the schools was transferred to a board of trustees, composed of two persons elected from each of the wards. ${ }^{104}$ Police administration fell theoretical ly within the jurisdiction of the mayor and, after 1868, the administration of fire protection was in the hands of a popularly elected chief engineer of the fire department.

On the other hand, the area of greatest municipal activity during this period, that of public work was more directly under council control. In 1855 an engineer department was created, hoaded by a qualified engineer, chosen by joint action of the two boards and an assistant

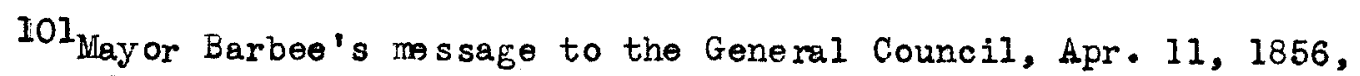
Louisville Journal, Apr. 14, 1856.

102Collins, op. cit., Vol. 1, p. 222.

${ }^{103}$ Charter of 1851, Art. VII, Sec. 17.

${ }^{104}$ Ibid., Art. $\mathrm{X}$, Sec. 1. 
chosen by the engineer, both subject to removal at will by the council. 105 The duties of the engineer consisted primarily of making out plans, specifications and estimates for public works and drawing up contracts for the approval of the mayor and council. 106

During this period there was a tremendous expansion in construction. In 1860 after many years of negotiation, the water works was finally erected and by the close of 1866 the city had forty-four miles of pipe and a daily consumption of some two million gallons of water. ${ }^{107}$ In 1853 the city council had subscribed $\$ 100,000$ for the improvement of streets and wharf $f^{108}$ and in 1860 was empowered by the assembly to provide for the construction of sewers. 109 By 1868 the city boasted of two hundred miles of streets and $42 \frac{1}{2}$ miles of street railway tracks, constructed by three companies which had received their franchises from the general council between 1864 and 1866 .

The Council and the Legislature

From the earliest days of government under the original act of

${ }^{105}$ Ordinance establishing and rogulating the Engineer's Department, May 19, 1855, in Collection of Acts, 1857, p. 187.

${ }^{106}$ Ordinance prescribing Duties of the Engineer, Nor. 5, 1853, in Ibid., p. 188 .

107 Edward (ed), Louisvillo Directory, 1867-1868, Louisvilles Southern Publishing Co., 1869, p. 74 .

${ }^{108}$ Louis ville Democrat, May 10, 1853.

109 Amend., Mar. 2, 1860, 10c. cit. 
incorporation, public meoting had been cell ad by the council for the purpose of acquainting the citizens of Louisville with proposed amendments to the city charter. Whether or not any expression of public opinion, by vote or otherwise, was ascertained at these meetings, or what influence such opinion, if it was determined, had on the legislative representatives, is not known; but, in any event, such expression had no legal validity. The 1851 charter, however, did attempt to give the voters of Louis villo a voice in certain matters of local concern. The charter, while permitting the council to "contract debts and liabilities.. - beyond the amount of revenues of the current fiscal yeer" required that such an ordinance bo published "at least three times in two daily newspapers" and be approved at a general or special election held at least sixty days after the first date of publication. 110 Moreover, no amendment to the charter could be presented by the council to the legisleture unless approved by a majority of the qualified roters at a general municipal election. If approved, the amendment was then subject to enactment by the Kentucky legislature. 11 Such provision served only to limit the power of the general council; the actions of the general assembly were in no wise restricted, since the latter reserved for themselves the right to "change, alter,

$110_{\text {This }}$ was charg ed to publication not more than thirty or less than ten days prior to the election date by Amend., May 15, 1861, Sec. 2, in Elliott, 으. cit., pp. $314-15$.

${ }^{111}$ Charter of 1851 , Art. XIII, Sec. 9. 
or repeal" the act at will. 112

The legislature, moreover, indulged freely in its rights. In the years between 1850 and 1870 more than 150 laws affecting Louisville were enacted. Some of these were passed at the request of the city, to be sure, but had the legislature been less prone to legislate on thers of purely local concern, the ever recurring need for amendment probably would have been considerably lessened. One noteworthy illustration of such local regulation sas the charter provision for the election of watchmen. 113 Within three years of the passage of the act, the increased population of the city had necessitated a larger police force; yet, the council lacked anthority to remedy the condition effectively, especially since the citizens failed to approve at the polis a proposed amendment on the subject. 114

Many of the acts concerning Louisville did not originate in the chambers of the general council. In 1868 the mayor complained that

Enactments vitally affecting our interests only are made at nearly every session of the legislature that have never been thought of or heard of by our citizens until the find them a law, and frequently, as I have reason to believe, are lobbied through by

112. Charter of 1851, Art. XIII, Sec. 11.

113 Charter of 1851, Art. IV, Sec. 8.

${ }^{114}$ General Council Proceedings, January 12, 1854, published in Louisville Democrat, Jan. 13, 1854; possibly a single amendment on the subject of police organization would have passed at this time; the amendments submitted, however, constituted practically a complete charter revision, and the voters had only the privilege of voting "for the amendments" or "against the amendments." 
individuals who have private and selfish ends to achieve... 115 To trace any particular piece of legislation of this period through its lobbyists to the original source of financial or other interest would be extremelydifficult and outside the scope of this writing. It was, however, the hey-day of corruption, and no one was more aware of it than Mayor Tomppert ho had been victimized in an attempt to stem its tide a few years earlier. 116

The subject of the police organization act of 1868 deserves more then passing attention as a departure from the previous practice in local government in Kentucky. It was an attempt by the state legislature to remove the police functions from municipal control and was passed over the objections of the Louis ville General Council. 117 By this act a police board sastablished comprising three commissioners elected by the voters of Jefferson County. The police officers, consisting of a superintendent of police, clerk, and lieutenants (their number being determined by the board) were chosen annually by the police board and were subject to removal by the same body for "good cause or any misconduct."118 At best it was an attempt to establish responsibility for

115 Mayor Tomppert's Annual Message to the General Council, LouisVille Democrat, Apr. 17, 1868 .

116 Supra, pp. $14-15$.

117 Journal of the Board of Ald ermen, Vol. 11, Jan. 20, 1868, p.288.

118 An Act providing for the Organization of a Police Force for the City of Louisville and Jefferson County, Feb. 24, 1868, Acts of the General Assembly, 1868, Ch. 549, Secs. 3, 8, 14 . 
an efficient police force. On the other hand, there is no doubt that the council was deprived of self-government to a certain degree. Despite the coordination of the city and county police under a single board, the two forces continued to operate as separate units and were even financed separately, a fact which would seem to negate any of the advantages of such coordination. The general council was, moreover, placed in the position of appropriating annually an amount over which it had littlo control to finance a governmental function outside its jurisdiction. The police board each year presented its budget for the city to the general council wo were required

- - in the appropriation ordi nance for that year, to set apart and appropriate the amount so certified [sic] payable out of the not annual revenue of said city; provided, however, that such estimate shall not exceed the aggregate amount of the salaries of the commissioners, officers, policemen, and clerks specified.. - and a reasonable [sic amount in addition thereto for of fice rent, fuel, stationery, and other necessery office expenses... II'

The mayor entered protest against the passage of the act on the grounds of unconstitutionality and refused to relieve the existing police; meanwile, the commis sioners made their appointments.120 The general council sought, over the mayor's veto, to resolve the issue by electing the same police as had been appointed by the commissioners.121 The question s ultimately submitted in a petition for

$$
{ }^{119} \text { Ibid., Sec. } 14 \text {. }
$$

120 Louis ville Democrat, Apr. 23 and May 9, 1868 .

${ }^{121}$ Proceedings of the General Council, Louis ville Daily Democrat, May 22, 1868 . 
mandamus to the Court of Appeals which declared the Act of 1868 constitutional. 122 Within two years, however, police administration underwent further changes in the new charter adopted March 3, 1870.123

Such legislative measures establishing independent or quasiindependent boards or comissions, ile transient in this local instance, were fairly widespread in many other states during the decades of the fifties and sixties. The New York legislature, in reaction against the infamous "Forty Thieves Council" of 1852, began the next year a period of state interference in manicipal affairs of the City of New York. In 1857 police power was vested in a metropolitan police board, originally appointed by the governor, and afterwards elected by the legislature; control of the police was not returned to the municipality until $1870 .^{124}$ similarly, Baltimore, after a period of four years of Know-Nothing party rule during which time the city was subjected yearly to the terror of election riots, in 1860 turned over control of its police system to a Board of Police Commis sioners composed of the mayor and four residents of Baltimore appointed by the general assembly. 125 More comparable to the Louis ville and Jefferson

${ }^{122}$ Pollee Commissioner v. City of Louisville, 3 Bush 599. 123 Charter of 1870 , Secs. 32-33.

124 Munro, Government of Ame rican Cities, pp. 18-19; Cyclopedia of American Government, pp. $\overline{54} 1-42$.

125T. P. Thomas, "The City Government of Baltimore," Baltimore, 1896 (Johns Hopkins University Stadies in Historical and Political Science, XIV, no. 2), pp. 68-69. 
County Police Board were the popularly and independently elected boards found in many cities, such as the Cleveland Board of Waterworks establishod in 1852 and the Chicago water-board of 1851; the latter was even empowered to borrow money in its own right. 126 In general, state legislatures tend ed to place adminis tration of many municipal activities in the hands of boards, either chosen by the state or popularly elected. As new municipal functions grew in importance, local councils became relatively weaker; administration and responsibility tended to become more and more decentralized; and municipalities found themselves in the penumbra of corruption.

Nor did the charter of 1870 offer much relief to Louisville government. In April, 1868, the question of a charter convention had been submitted to the voters and had been approved by an overwhelming majority ${ }^{127}$ Delegates were elected and a new charter drawn up in accordance with the procedure prescribed by the 1851 charter:

The general council ma call a convention of delegates from each ward, to be elected by the qualified voters thereof . . . which convention - . may amend this charter or make a new one, which amendments or new charter shal 1 first be submitted to the qualified voters of the city . - and if approved by a majority of the said voters roting for or against the same, and enacted by the legislature of Kentucky, the same shall form part or supercede the charter. 128

\footnotetext{
${ }^{126}$ Fairlie, Municipal Administration, p. 88 .

127 Louis ville Democrat, Apr. 5, 1868; vote for charter convention, 4944 ; against, 1358 .

${ }^{128}$ Charter of 1851, Art. XIII, Sec. 9.
} 
By 1870 the sie and population of the city had increased substantially, 129 and the now charter in general provided for the extended municipal functions which attended this growth. Provision was made for condemnation of property, diviston of the city into districts for the construction of public works, devel opment of parks and maintenance and repair of public ways. It al so provided for regulation of street railways, leveeing, municlpal planning, and the erection of a city hall. 130 Twelve sections were devoted to the management and finance of schools, and the subject of public charities received more attention than formerly. 131

The framework of the gor ermment was essentially the samo as that provided by the 1851 charter and subsequent amendments. The same officers were elective with substantially the same powers and duties. There were, however, a few modifications. The mayor's term of office was extended to three years, and he became ineligible for of fice during the ensuing three years; qualifications for municipal office were slightly modified in that residen within the city for fo ve years was made requisite for all offices; and the date of election was moved from April to the first Tuesday in December. 132

129 Population of Louisville in 1850 had been 43,194 and by 1870 it had increased to 100,753 .

130 Charter of 1870 , Secs. $10,12,13,15,16,17,64$.

$13 I_{\text {Ibid., Secs. } 76-95 .}$

132 Ibid., Secs. 19-20. 
CHARTER OF 1870

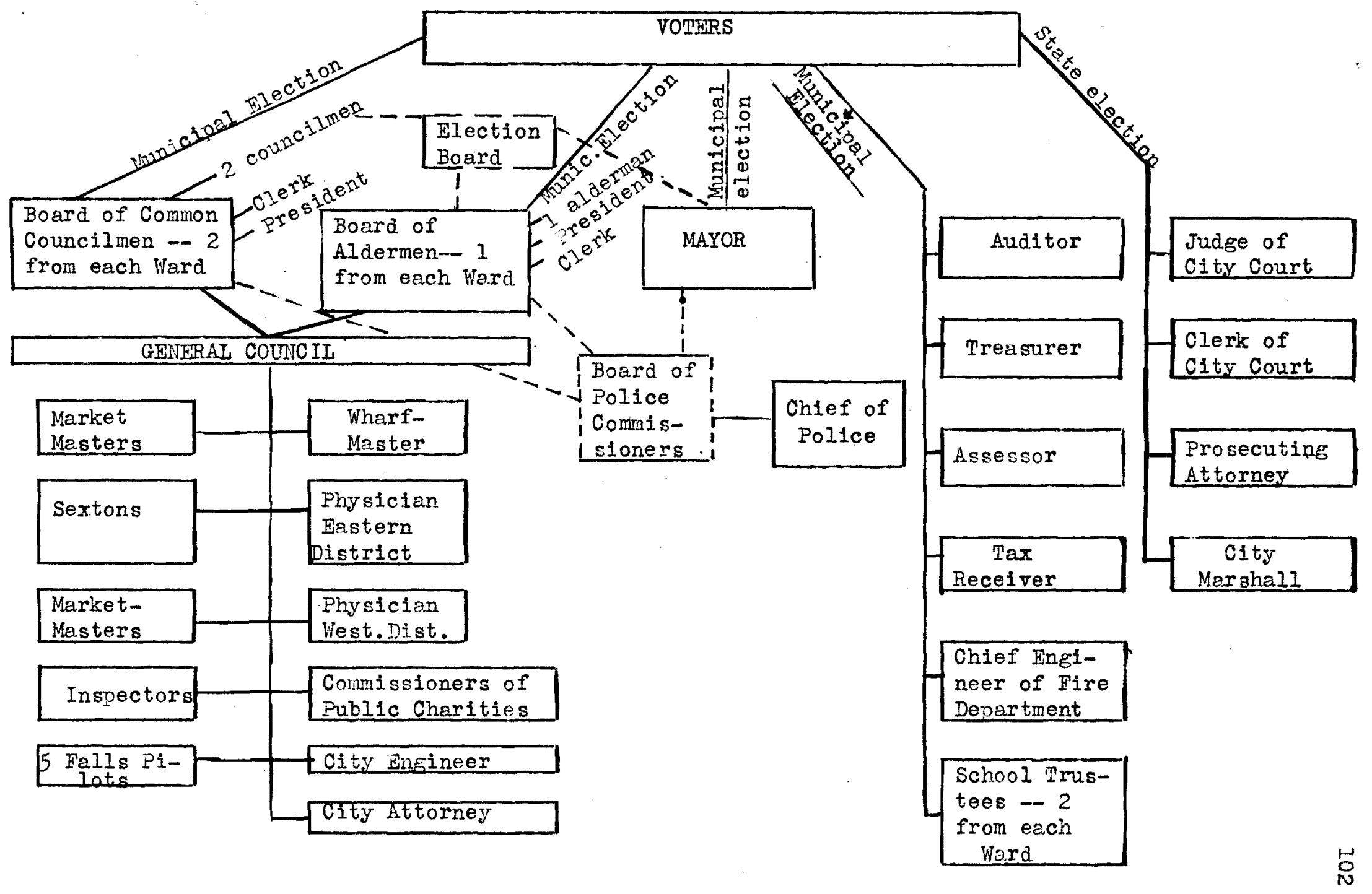


The chief reform instituted by the 1870 charter was the reorganization of the police force. For the first time in the history of the city, policemen were required to meet more stringent qualifications than that of being a voter. In addition to being white, United States citizens who had resided in the city a minimum of three years, police were required to be at least twenty-four years of age, "moral, sober, and sagacious" and it was further stipulated that "none of them shall interfere in elections further than to vote." Also, for the first time the police force was organized on a semi-military basis with distinctions of rank and uniform. ${ }^{133}$ In charge of the police organization was a Board of Police Commissioners, composed of the masor, the president of each board of the council, and the Chairman of the Police Committee of each board, who annually elected the entire police force except the police chief who was nominated by the mayor and confirmed by the board. 134 Inasmuch as the tenure for police was one year and the force included in addition to the chief, two first lieutenants, elght second-lieutenants, and one hundred fifty policemen, 135 one may easily conjecture as to the morality, sobriety, and sagacity of the force!

${ }^{133}$ Charter of 1870 , Sec. 32 .

134 Ibid., Secs. $33,34$.

1350ra. No. 392, March 23, 1870, in Charter of City of LouisVille and Ordinances prepared by Oliver Iucas, 1873, p. 130 . 
The board of commissioners of public charities, established by the 1870 charter coordinated the functions of the previous boards for the various charitable institutions under one management, including under their control the Louisville Marine Hospital, the alms houge, the pest house, the city workhouse, houses of refuge and similar institutions. The board itself comprising the moyor with six other nembers with the same qualifications as aldermen were elected by the general council. Its members served without pay for staggered terms of three years; they passed regulations, appointed superintendents and all employees of the institutions, fixed salaries and heard complaints of inmates. The board was prohibited from creating indebtedness and its expenditures were limited to the amount appropriated for that purpose by the council. 136

The paid fire department which had superseded the volunteer fire companies in 1858 was continued in the later charter. The chief engineer continued to be elected for a two-year term by the city roters and had the power of appointment of all subordinates subject to the approval of the general council. 137

That the 1870 charter to some extent provided needed reform in the reorganization and coordination of manicipal functions, particularly in the areas of police, fire, and welfare administration

${ }^{136}$ Charter of 1870, Seca. 89-95.

137 Ibid., Secs. 101-103. 
is evident. But the real weaknesses inherent in the loosely constructed framework of the government, the absence of governmental responsibility, remalned, providing ample opportunity for the continuation of the spoils system. 
SUMMARY

The period between 1780 and 1870 witnessed extraordinary changes in municipal government in the United States. The franchise, which usually had been limited during the latter part of the eighteenth century to a small group of property-holders, had gradualiy been extended until by 1850 the principle of white manhood suffrage was generally accepted.

In Louisville municipal affairs the franchise had had little meaning so long as the trustees vere appointed by the Virginia Legislature. When the town of Loutsvilie passed under the control of the Kentucky Legislature and the offices of the trustees for the first time became elective, suffrage in manicipal elections was extended in accordance with provisions of the constitution to all free males who had lived in the state and in the county one year. This was a higher residence qualification than found in most frontier states, but the absence of property or tax-paying qualifications was in keeping with the growing spirit of Iiberalism of the west. ${ }^{I}$ The Kentucky Constitution of 1799 excluded negroes, mulattoes, and Indians from the polls; later, an amendment to Louisville's first charter Imposed taxpaying qualifications on voters. Actually, while prior to 1850 roting qualifications were gradually being liberalized in most other cities, in Louisville the trend was in the opposite

I Kirk H. Porter, A History of Suffrage in the United Stateg, Chicago, 1918, p. 24. 
direction. The taxpaying qualification, however, was abolished by the charter of 1851 and eren the length of residence was shortened by subsequent amendment. Negroes did not vote until after the first municipal election under the new charter of 1870. The Kentucky constitutional provision excluding negroes, mulattoes, and Indians from the polls remained effective until the ratification of the fifteenth amendment to the Federal Constitution on March 30,1870 , twenty-fire days after the municipal election on March $5 .^{2}$

Along with the extension of suffrage, there was a gradual increase in popularly elective offices. While councll members since colonial days had been elected by popular vote in most cities, it was not until after 1820 that the office of mayor was made elective; after 1850 roters in many cities elected a large number of public officials, heads of departments, and independent boards. If certain practices well established in the larger cities were adopted in Louisville only after a lapse of years, the time lag can partially be accounted for by its lesser population. Thus it was that Louisville passed through the stages of having a mayor appointed by the state, chosen by the council and finaliy elected by popalar vote -- an experience common to other municipalities some years earlier.

The structure of municipal government likewise underwent

Zentucky did not ratify the Fifteenth Amendment. KY. House Journal, 1869, p. 776 ; Senate Journal, 1869, p. 628 . 
modifications. While prior to 1820, typically, a unicameral council exercised both legislative and executive, and in some few instances, judicial functions, there was a tendency in the charters adopted after 1820, to incorporate the bicameral system of council organization and mayoral veto. After 1850 the power of the council decreased with the disintegration of municipal functions into independent boards or departments. Until after 1870 the position of mayor was one of prestige rather than of power.

In ninety years Louisville had experienced various changes in gorernment. The trustees appointed by the Virginia legislature had been chiefly concerned with fighting Indians and selling lots; their powers were few, and their functions limited chiefly to the improvement of streets and the establishment of markets with whatever revenue was derived from the sale of lots. Iater trustees, whose offices became elective by Kentucky law in 1796, were accorded slightly broader powers, including a limited power of taxation, but their functions constituted hardly more than petty housekeeping. In 1828, under pressure of the growing population, Loulsville was incorporated. The trustees were replaced by a popularly elected mayor and council, whose powers were increased as municipal activities continued to expand. Both administrative and legislative functions were performed by the unicameral council; the mayor was the executive head but his powers were chiefly advisory.

The turning point in the development of municipal government in Louisville came with the adoption of the charter of 1851. 
Administration through council committees became increasingly impracticable as the city grew and municipal functions increased. The 1851 charter introduced the bicameral council and the mayoral veto: leglslative, and executive functions became differentiated for the first time in the history of Loutsville government. A number of city offices were made elective, and administration of most municipal actirities passed out of the hands of the council to elected or appointed officials or to boards, popularly elected like the school board or chosen by the council, like the health board.

The fundamental idea of American government that "the people are the source of all political power and have the right to exercise $1 t^{13}$ extended not to suffrage alone but to the right of self-government by the local community. Although home rule in the modern sense was not introduced until Missouri established the precedent in $1875,{ }^{4}$ charters of the larger cities were not uncommonly locally initiated. The New York City charters of 1830 and 1849 were framed by conventions of delegates elected by wards and ratified by the citizens before being enacted into law by the

3Dilion, J.F., Commentaries on the Law of Municipal Corporations, Vol. I, Ch. 15. Sec. 9, p. 25 .

Macdonald, op. cit., pp. 59, 76-77. 
State assembly, ${ }^{5}$ as was the Loulsville Charter of 1850 . What was true of charters was likewise true of most monicipal legislation. Prior to 1850 most laws regulating local affairs were drafted by the local community or at least embodied the will of the local council. After 1850, however, many state legislatures began to impose restrictions on municipalities without regard to local interests or welfare. Boards entrugted with matters of vital concern to the city were of ten made independent of the council or mayor of the maniclpality. The only instance of this in Louisville prior to 1870, however, was the Police Board created in 1868. Cities, in brief, struggled to obtain legialation they desired or to prevent the passage of legislation they considered detrimental to their interests - a situation which to a large extent still exists.

Throughout the nineteenth century the trend was toward expanding urbanization, but it was not until after 1880 that cities assumed a role of importance in national life. Eren in 1870 there were but 226 municipalities with populations exceeding 8000 . Until 1820 the growth of cities was slow and municipal activities, correspondingly meager. Between 1820 and 1850 municipal functions were expanded to some extent, and the period following 1850 is

5 Gyclopedia of American Government, pp. 541-2.

6rneir, op. cit., pp. 54-55. 
characterized by a rapid extension of municipal functions. Such expansion was attended by rapidly mounting manicipal expenditure and by the growing development of the spoils system. Municipal functions multiplied as the greater population created new demands, but the structure of government, for the most part, was not flexible enough to meet the challenge of this expansion. By 1870, most cities found themselves in the doldrums of corruption which elicited from the British political scientist some years later the remark that the government of cities was "the one conspicuous failure of the United States."7 The challenge was only partially met by the reform governments which rose to power from time to time in the period following 1870. It was not until the twentieth century that basic reforms in the structure of municipal government were effected.

Louisville in 1870 was a rapidly growing city; in twenty years her population had more than doubled, and within the next thirty years it was to double again. Since 1850 the city had been engaged in expanding private business and public construction. Investments, both public and private, in railroads were tremendous. The first bridge connecting Louisville with the North had been completed, and already the importance of river traffic was beginning to decline. Since 1839 the city had been lighted by gas; the water works had been in operation for ten years, and the central

\footnotetext{
T Bryce, James, American Commonwealth, Vol. I, N.Y.,
} Macmillan, 1896, p. $60 \overline{8}$. 
part of the city was serviced by a sewer system. Horse-drawn street-cars traversed a number of streets. The courthouse had been completed and the city hall was under construction. Louisville now had an organized police department and a municipally operated fire department. The school system was growing, and health and charities were receiving increased attention.

Since 1870 Louisville has had two new charters. The 1893 charter in some respects improved government by relieving the council of details of administration with which it previously had been saddled, but the framework of government which it estabIished was clumsy and the responsibility of government was disseminated among a large number of elective offices. It was not until 1926 that efforts toward streamling and simplifying the structure were achieved. 


\section{BIBLIOGRAPHY}

\section{PRIMARY SOURCES}

\section{A. MANUSCRIPT DOCUMBN TS}

City Journal, Vols. I-XIV. Unpublished Proceedings of the City Council. Louisville, Ky. 1828-1851.

Journal of the Board of Aldermen. Vols. I-12. Louisville, Ky. 1851-1870.

Journal of the Common Council. Vols. 1-12. Louisville, Ky. 1851-1870.

Record of the Town of Louisville. Unpublished Minutes of the Board of Trustees. Louisvilie, Ky. 1781-1827.

\section{B. PUBLI SHED DOCUMENTS}

Acts of the Commonwealth of Kentucky. 1828-1870. Published by authority. Frankfort, $\mathrm{K} y$. 1829-1871.

Bush, W. P. D., reporter, Reports of Selected Civil and Criminal Cases decided in Court of Appeals of Kentucky. 3 vols. Louisville: John P. Morton. 1867-1869.

Charter of the City of Louisville adopted March 3, 1870: Amendments to the Charter, Acts of the General Assembly of a Local Character, and Ordinances of the City, June 24, 1869 - January 1, 1873. Prepared by Oliver Lucas. Louisville: John P. Morton. 1873. $440 \mathrm{pp}$.

Collection of Acts of Virginia and Kentucky. Prepared under direction of Mayor and Councll. Loulsville, Ky. Prentice and Weissinger. 1839 .

Durall, Alvin. Reports of the Court of Appeals of Kentucky. 2 rols. Frankfort, Ky. Ky. Yeomen Office. 1865-1867.

Elliott, Robert J., compiler. Charter of the City of Louf sville of 1851 and Ordinances of the City in force on the 24 th of June 1869. Prepared under direction of the General Council. Louisville, Ky. 1869.

The Kentucky Iaw Reporter. Frankfort, Ky. 
Laws of Kentucky, 1867. 2 rols.

Iittell, William and Swigert, Jacob, compilers. Digest of the Statute Law of Kentucky. 2 vols. Frankfort, Ky. 1822.

Metcalf, J. P. Reports of the Court of Appeals of Kentucky. 4 rols. Frankfort. A. G. Hodges. 1859-1864.

Report of the Debates and Proceedings of the Convention for the Rerision of the Constitution of the State of Kentucky. Frankfort. Ky. 1849 .

Revised Ordinances of the City of Louisville. Louisville, Ky .: W.N. Haldeman and Company. 1854.

Robertson, James R., Petitions of the Farly Inhabitants of Kentucky to the General Assembly of Virginia, 1769-1792. Loutsville, 1914. (Filson Club Publication, No. 27).

Toulmin, Harry, editor. Kentucky Iaws, 1797. Frankfort, Ky.: Wm. Hunter, 1802 .

Young, Bennett H., History and Texts of the Three Constitutions of Kentucky . Louisville, Ky.: Courier-Journal Job Printing Company, 1890. $122 \mathrm{pp}$.

\section{NEWSPAPERS}

American Democrat and Weekly Courier, February 1, 1845 - October 3 , 1846.

Daily Loui sville Herald and Commercial Gazette, August 2, 1832 March 9, 1833 .

The Thaminer, June 10, 1848 - December 1, 1849.

Iouisville Daily Cour1er, January 1, 1851 - September 18, 1861; December 4, 1865 - October 31, 1868 .

Louisville Daily Democrat, January 3, 1851 - June 30, 1854; January I, 1857 - May 4, 1860; January 2, 1865 - December 30, 1865; January 1, 1867 - December 31, 1868.

Loui sville Daily Journal, May 3, 1836 - December 29, 1836; December 1, 1840 - November 7, 1868 .

Loui sville Journal (Weekly), August 24, 1836 - March 11, 1840; May 21, 1845 - May 24, 1854. 
Ioul sville Pablic Adrertiser, December 18, 1840 - January 9, 1844; 1827 - 1828 (odd numbers).

Louisville Weekly Courier, October 10, 1846 - December 29, 1849.

\section{MISCELIUANEOUS}

Department of Commerce and Labor, J. S. Bureau of the Census. A Century of Population Growth, 1790-1900. Washington. D. C. Government Printing Office. 1909.

U. S. Bureau of Census. The Serenth Census of the United States, 1850. Washington, D.C. Government Printing Office. 1853.

J. S. Census Office. Sixth Census of the United States, 1840. Washington, D. C. Government Printing Office. 1841.

\section{SIRCONDARY SOURCBS}

Allinson, Ddward P. and Penrose, Boles. "The City Gorernment of Philadelphia." Baltimore. 1887. (Johns Hopkins University Studies in Historical and Political Science, Fifth Series, Nos. I-II, January - February 1887.)

Beard, Charles A. American City Government. New York: Century, 1912.

Macmillan, 1936. American Government and Politics. New York:

Bryce, James, The American Commonwealth, Vol. I, New York: Macmillan, 1891.

Bugbee, James M., "The City Government of Boston." Baltimore, 1887. (Johns Hopkins University Studies in Historical and Political Science, Fifth Series, No. III, March 1887.)

Casseday, Benjamin. History of Louisville from Its Settlement to the Year 1852. Loui sville: Hull, 1852 .

Chandler, Julian A. C., "The History of Suffrage in Virginia." Baltimore. 1901. (Johns Hopkins University Studies in Historical and Political Science, XIX, Nos. 6-7, June - July, 1901.)

Collins, Lewis. History of Kentucky. 2 vols. Revised by R. C. Collins. Covington, Ky.: Collins and Company, 1874. 
Dillon, John F.. Commentaries on the Law of Municipal Corporations. 5 rols. Fifth edition. Boston: Iittle, Brown, 1911. Vol. I, pp. $1-56$.

Fdward, editor, Louisville Directory, 1867-68 Louisville: Southern Publishing Co. 1869.

Fairlie, John A., Essays in Municipal Administration. New York: Macmillan, 1908. 1901. $431 \mathrm{pp}$.

- Municipal Administration. New York: Macmillan

Goodnow, Prank J., City Government in the United States. New York: Century, 1904. and Bates, Frank G., Municipal Government. Revised edition. New York: Century, 1925.

History of the Ohio Falls Citios, Vol. I. Cleveland: I. A. Wili iams and Company. $\frac{\text { 1882. }}{182}$

Howe, William W., "Municipal History of New Orleans." Baltimore. 1889. (Johns Hopkins University Studies in Historical and Political Science, VII, No. 4, pp. 159-I87).

Jennings, Kathleen. Loulsville's Flrst Pamilies. Louisville: St andard Printing Company, 1920. 175 pp.

Johnston, J. Stodard, editor. Memorial History of Louisville, Vol. I. Chicago: American Biog. Publishing Company, $18 \overline{96 .}$

Knoir, Charles M., City Government in the United States. New York: Harper, 1934. $459 \mathrm{pp}$.

Iouisville Iibrary Collections. Institutions Series, Vol. I. Collected Writings Relating to Institutions of Louisville. Reproduced by the Loulsville Free Public Library. Lonisville, Ky. 1935.

MacDonald, Austin F. American City Government and Administration. New York: Crowell. Ig42. $636 \mathrm{pp}$.

Mclaughlin, Andrew C. and Hart, Albert B., editors. Cyclopedia of American Government; 3 vols. New York: Appleton, 1914.

M'Murtrie, Henry. Sketches of Louisville. Loulsville, Kentucky: S. Penn. 1819. 
Munro, William Bennett. The Government of American Cities. New York: Macmillan, $1920,440 \mathrm{pp}$.

Manicipal Government and Administration. New York: Macmillan, 1930. 459 pp.

Otis, Richard W.. editor. The Louisville Directory. Louisville, Otis, 1832. $198 \mathrm{pp}$.

Patton, Clifford W., The Battle for Municipal Reform, 1875-1900. American Council on Public Affairs. Washington, D. C. 1940. $76 \mathrm{pp}$.

Porter, Kirk H.,A History of Suffrage in the United States. Chicago: University of Chicago Press, $1918.254 \mathrm{pp}$.

Reed, Thomas Harrison, Municipal Government in the United States. New York: Appleton-Century, 1934.

Snow, Marshall S., "The City Government of St. Louis." Baltimore, 1887. (Johns Hopkins University Studies in Historical and Political Sclence, Fifth Series, No. IV, April 1887.)

Thomas, Thaddeus P., "The City Government of Baltimore." Baltimore. 1896. (Johns Hopkins University Studies in Historical and Political Science, XIV, NO. 2, pp. 47-91.)

Weber, Adna Ferrin, The Growth of Cities in the Nineteenth Century: A Study in Statistics. New York: Macmillan, 1899. (Columbia University Studies in History, Economics and Public Law, VoI. XI.)

Wilson, Samuel M., History of Kentucky. 2 rols. Chicago: S. J. Clarke Publishing Company, 1928. 